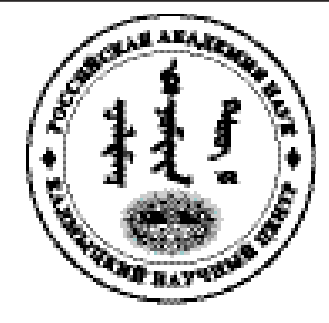

Published in the Russian Federation

Oriental Studies (Previous Name: Bulletin of the Kalmyk Institute

for Humanities of the Russian Academy of Sciences)

Has been issued as a journal since 2008

ISSN: 2619-0990; E-ISSN: 2619-1008

Vol. 13, Is. 4, pp. 1018-1044, 2020

DOI: 10.22162/2619-0990-2020-50-4-1018-1044

Journal homepage: https://kigiran.elpub.ru

УДК $294.3+003.335$

DOI: 10.22162/2619-0990-2020-50-4-1018-1044

\title{
Гадание посредством Авалокитешвары
}

\author{
Бембя Леонидович Митруев ${ }^{1}$
}

${ }^{1}$ Калмыцкий научный центр РАН (д. 8, ул. И. К. Илишкина, 358000 Элиста, Российская

Федерация)

научный сотрудник

iD 0000-0002-1129-9656. E-mail: bemitrouev@yahoo.com

(c) КалмНЦ РАН, 2020

(C) Митруев Б. Л., 2020

Аннотация. Введение. В статье рассматриваются ойратский и тибетский тексты гадания, проводимого посредством Авалокитешвары. Это гадание представляет интерес для изучения религиозных практик и верований ойратов Западной Монголии. Цель статьи - ввести в научный оборот ойратский текст гадания, имевший хождение в Западной Монголии, а также и тибетскую версию этого гадания. Материаль. Материалы для данной статьи были получены из двух источников. Ойратский текст был взят из коллекции Центра по изучению истории, языка и культуры ойратов «Свет ,ясного письма“» (Tod Nomin Gerel), который хранится на сайте цифровой библиотеки международных исследований (Digital Library for International Research). Коллекция «Tod nomin gerel» представляет собой собрание цифровых копий различных текстов на ойратском языке, записанных «ясным письмом» ('тодо бичиг') и текстов на тибетском языке. Тибетский текст гадания был получен автором во время стажировки в Улан-Баторе в 2012-2013 гг. от Амарбаясгалан Улзийбата, проживающего в Улан-Баторе. Meтоды. В статье использованы сравнительно-сопоставительный метод, а также метод контекстуального анализа. Результаты. Сопоставление ойратского и тибетского текстов дает возможность предположить, что тибетский текст представляет собой перевод с монгольского или ойратского. Такая практика имела место в монгольском обществе. Данное исследование представляет собой интерес для сравнительного изучения гадательных традиций в Тибете и Монголии, а также процесса генерации подобных текстов и переводческой практики в традиционном обществе.

Ключевые слова: гадание, тодо бичиг, ясное письмо, Авалокитешвара

Благодарность. Исследование выполнено при финансовой поддержке гранта в форме субсидии из федерального бюджета, выделяемой для государственной поддержки научных исследований, проводимых под руководством ведущего ученого (проект «От палеогенетики до культурной антропологии: комплексное интердисциплинарное исследование традиций 
народов трансграничных регионов: миграции, межкультурное взаимодействие и картина мира»).

Для цитирования: Митруев Б. Л. Гадание посредством Авалокитешвары // Oriental Studies. 2020. T. 13. № 4. C. 1018-1044. DOI: 10.22162/2619-0990-2020-50-4-1018-1044

UDC $294.3+003.335$

DOI: 10.22162/2619-0990-2020-50-4-1018-1044

\title{
Avalokiteshvara Dice Divination
}

\author{
Bembya L. Mitruev ${ }^{1}$
}

${ }^{1}$ Kalmyk Scientific Center of the RAS (8, Ilishkin St., Elista 358000, Russian Federation)

Research Associate

iD 0000-0002-1129-9656. E-mail: bemitrouev@yahoo.com

(C) KalmSC RAS, 2020

(C) Mitruev B. L., 2020

\begin{abstract}
Introduction. The article discusses the Oirat and Tibetan texts of Avalokiteshvara divination. Goals. The paper aims to introduce the Oirat fortune-telling text (which was in use in Western Mongolia) and its Tibetan version into scientific circulation. The divination is instrumental in studying religious practices and beliefs of the Oirats of Western Mongolia. Materials. Materials for the article were obtained from two sources. The Oirat text was borrowed from the collection titled The Light of Clear Script Texts (Mong. Tod Nomin Gerel) which is stored on the website of the Digital Library for International Research. The Tod Nomin Gerel Collection comprises digital copies of various Oirat-language texts written in 'Clear Script' and those of Tibetan-language ones. The Tibetan divination text was obtained by the author during language training in Ulaanbaatar in 2012-2013 from Amarbayasgalan Ulzibat, resident of Ulaanbaatar. Methods. The article employs the comparative method and that of contextual analysis. Results. A comparison of the Oirat and Tibetan texts makes it possible to assume that the Tibetan text is a translation from Mongolian/Oirat. This practice was inherent to Mongolian society. Thus, the study is of interest due to an opportunity to get comparative insights into fortune-telling traditions of Tibet and Mongolia, as well as the process of generating such texts and translation practices in traditional society.
\end{abstract}

Keywords: fortune telling, Todo Bichig, Clear Script, Avalokiteshvara

Acknowledgements. The reported study was funded by government grant in the form of federal budget subsidy aimed to support scientific research directed by the Leading Scientist — project name 'From Paleogenetics to Cultural Anthropology: Comprehensive Interdisciplinary Research of Peoples and Traditions of Cross-Border Regions - Migrations, Cross-Cultural Interactions and Worldviews'. For citation: Mitruev B. L. Avalokiteshvara Dice Divination. Oriental Studies. 2020. Vol. 13(4): 1018-1044. (In Russ.). DOI: 10.22162/2619-0990-2020-50-4-1018-1044

\section{है}

\section{Введение}

Человечество всегда волновало его будущее. Люди хотели знать, что их ждет. Для этой цели использовались различные формы гадания, в том числе и гадания на костях. Ко- сти использовались для гадания в древней Греции, Византии, Китае и т. д. Первоначально для гаданий на костях использовали четырехгранные кости, которые затем превратились в шестигранные. 
В тибетском каноне, а именно в 211 томе нартангского Тенгьюра ${ }^{1}$, сохранился текст, называющийся на санскрите «Кевали» (санскр. kevalī 'гадальные кости') и приписываемый Шантидэве. Это сочинение, в котором говорится об использовании четырехгранных костей, было переведено с санскрита на тибетский язык под названием «Гадание Манджушри» (тиб. mo rtsis 'jam pa'i dbyangs) [mo rtsis].

Этот способ гадания описан в книге «Гадание народов мира» [Опря 1990: 74-77], а также в книге «Гадание посредством Ачи и Тары», посвященной гаданиям в целом, а в особенности гаданию на четках посредством Тары [Sobisch, Hyveled 2019: 6].

Интересно отметить, что, по всей видимости, это же гадание присутствует во 2 томе собрания сочинений Бодонг Панчена Чогле Намгьяла (тиб. bo don pan chen phyogs las rnam rgyal), изданном Тибетским домом в Нью-Дели в 1969-1981 гг. под названием «Разъяснение гадания посредством бросания костей, объясненное Великолепным Шантидэвой» (тиб. dpal ldan zhi ba thas gsungs pa'i sho 'gyed pa'i mo rtsis bstan pa) [bo dong: 191-212]. Однако на момент обращения электронная копия текста Бодонг Панчена еще не была выложена на сайте Центра цифровых буддийских ресурсов (Buddhist Digital Resource Center).

Помимо этого, существует множество тибетских текстов гадания на костях, посвященных разным божествам, например, составленное Мипамом Ринпоче гадание посредством Манджушри, переведенное на русский язык [Мипам 2006]. Также можно упомянуть приписываемое Атише гадание посредством Тары, текст которого также переведен автором на русский язык, но не опубликован.

Одним из самых популярных текстов гадания в тибетской традиции является гадание через Палден Лхамо. Кроме этого, существуют гадания посредством Хаягривы, ламы Цонкапы [Митруев, Дугданов 2019], Дордже Легпы, Ямараджи, Сетраба и прочие [Митруев 2020]. Среди них есть

\footnotetext{
${ }^{1}$ Следуя произношению центрального Тибета, мы называем канонический свод трактатов, переведенных с санскрита и прочих языков на тибетский, - Тенгьюр, а не Данжур, как традиционно принято в российском монголоведении.
}

несколько гаданий на гадальных костях, посвященных Авалокитешваре.

Существует несколько текстов гаданий посредством Авалокитешвары на тибетском языке. В сборнике «Тексты гаданий, геомансии и методов исследования снов» (тиб. mo dpe sa dpyad rmi lam brtag thabs) представлено гадание посредством Авалокитешвары, озаглавленное «Практика высшего Арья Махакаруники ${ }^{2}$ „Зерцало, проясняющее острое видение“" (тиб. "phags mchog thugs rje chen po'i lag len rno mthong gsal ba'i me long) [tshe ring dang 'brug rgyal 1997: 107-124].

Другим гадательным тестом, очень схожим с вышеупомянутым, является гадательная книга, полученная от тибетского ламы Дуге Ринпоче Тендзин Ньимы (тиб. 'dug dge rin po che bstan 'dzin nyi ma) из тибетской провинции Амдо, который называется «Острое видение Высшего Арья Махакаруники „Ясное зерцало“» (тиб. "phags mchog thugs rje chen po'i rno mthong me long gsal ba).

На современном монгольском языке было опубликовано несколько текстов гадания посредством Авалокитешвары. В книге «Избранные методы применения в жизни монгольской астрологии и гаданий» (монг. Монгол зурхайн ухаан, мэргэ төлгийг амьдралдавч хэрэглэх шилдэг аргууд), составленной Д. Даваажавом и Д. Сугардоржем, представлено гадание под заглавием «Гадание на костях [посредством мантры] мани ${ }^{3} »$ (монг. Маанийн шооны мэргэ) [Даваажав, Сугардорж 2012: 61-62]. Также в сборнике гадательных текстов «Способы исследования монгольских традиционных гаданий» (монг. Монгол үндэсний мэргэ төлөг шинжихүй ёсон) под редакцией Ш. Сухбата, имеется гадание под названием «Гадание [посредством мантры] мани» (монг. Маанийн төлөг) [Сүхбат 2002: 79-80].

Интересно отметить, что гадание в книге Ш. Сухбата представляет собой сокращенный вариант гадания, опубликованного в книге Д. Даваажава и Д. Сугардоржа, котоpое, в свою очередь, очень схоже с текстом, рассматриваемым в данной статье. Другой монгольский текст гадания, местами прак-

2 Махакаруника, «Великосострадательный» — эпитет Авалокитешвары.

3 Шестислоговая мантра Авалокитешвары ом мани падме хум. 
тически идентичный рассматриваемому здесь ойратскому тексту, также опубликован в книге Ш. Сухбата «Способы исследования монгольских традиционных гаданий» под названием «Шооны төлөг шинжихүй» («Исследование гадания на кости») [Сүхбат 2002: 40-44]. Однако в этом тексте гадания нет упоминания мантры Авалокитешвары «om maṇi padme hūṃ», и интерпретации гадания определяются по количеству глазков на выпавшей грани кости. Тем не менее в самом конце текста стоит фраза: «Хоншим бодсадын айлдсан судар төгсвээ» ('Сутра, изреченная Авалокитешварой, завершена'), что указывает на то, что данное гадание связано с Авалокитешварой и, как следствие, с его мантрой.

От жителя Монголии Хухийн Бямбажава была получена копия еще одного текста на «ясном письме» под названием «Возвышенное гадание [посредством гадальной] кости мани» (ойр. Xutuqtu mani šotölögö orošoboi), на пяти листах. Этот текст довольно сильно отличается от текста, анализируемого в данной работе.

Целью исследования является введение в научный оборот двух текстов гадания посредством Авалокитешвары - «Гадание Авалокитешвары посредством гадальной кости» (ойр. Nidü-ber üzeqci-yin šō talbixui sudur $^{4}$ orošiboi) на «ясном письме» [Гадание Авалокитешвары 2011] и безымянный текст гадания посредством Авалокитешвары на тибетском языке [НА КалмНЦ РАН. Ф. 8. Оп. 3. Д. 181]. Предположительно, тибетский текст представляет собой перевод с ойратского или монгольского языка.

\section{Описание рукописей}

Ойратский текст гадания посредством Авалокитешвары был взят из электронной коллекции Центра изучению истории, языка и культуры ойратов «Свет ,ясного письма“"» (Tod nomin gerel). Оригинал хранится в захчинском монастыре Раашгонзэглин ${ }^{5}$ (тиб. bkra shis dkon brtsegs gling) сомона Манхан Кобдоского аймака Монголии. Копия текста хранится на сайте цифровой библиотеки международных исследований (Digital Library for International Research) под шифsudür.

${ }^{4}$ В оригинале ойратского текста написано:

${ }^{5}$ В переводе на монгольский: «Өлзийч ухаг давхарласан хийд». ром Barintag-06-15, Item \#11364. Название текста — «Гадание Авалокитешвары посредством гадальной кости» (ойр. Nidü-ber üzeqci-yin šō talbixui sudur orošiboi) [Гадание Авалокитешвары 2011]. Текст состоит из восьми листов, размер рукописи - 21,7х7,5 $\mathrm{cM}$.

Текст написан с ошибками, начиная с первой строки выражения поклонения, в которой написано «na lo šo ra уa», что, наиболее вероятно, является ошибочным написанием санскритской формулы поклонения «namo lokeśvarāya», где намо значит 'кланяюсь', а Локешварая - 'пред Владыкой мира', где «Владыка мира» - это эпитет Авалокитешвары.

В тексте присутствует много архаизмов. Например, šibišēd (деепричастная форма глагола šibiškü) не встречается во многих словарях калмыцкого языка, но есть в «Словаре языка ойратов Синьцзяна» со значением 'обращаться к божеству’ [Тодаева 2001: 453].

Другое слово ukāl ('омовение') есть в монгольском, но не встречается в словарях калмыцкого языка. Несмотря на это, имеются сведения о бытовании этого слова в калмыцком языке: так, американский калмык Бен Мошкин свидетельствовал об употреблении этого слова в калмыцком языке, которое он на слух записал как okal. Другими такими примерами могут быть zabxuul 'потеря, отбившийся скот' или temecel 'спор, конфликт', которое в современном калмыцком языке обрело значение 'стремление вперед' [КРС 1977: 492].

Интересно написание некоторых слов. Например, слово хөн, которое обычно пишется на «тодо бичиг» xonin, в данном тексте приводится в написании хоуіп. Такое же написание хоин дано в словаре Б. Х. Тодаевой в статье для слова хөөн [Тодаева 2001: 408]. Данный пример демонстрирует процесс сближения написания письменного языка с разговорным произношением.

Есть несколько словосочетаний, о смысле которых мы можем догадываться из контекста и которые, по-видимому, представляют собой идиоматические выражения. Например, словосочетание сүл ахр (букв. 'хвост короткий') имеет в тексте значение 'вскоре'. Слово arbijixu — 'преумножаться, увеличиваться’, однако отсутствует в Калмыцко-русском словаре под редакцией Б. Д. Муниева [КРС 1977]. 
Другой текст, рассматриваемый в данной статье, - безымянная тибетоязычная рукопись гадания посредством Авалокитешвары [НА КалмНЦ РАН. Ф. 8. Оп. 3. Д. 181]. Копия выполнена с рукописного текста из коллекции Улзийбат Амарбаясгалана, проживающего в Улан-Баторе. Этот текст включает в себя два сочинения: гадание посредством гадательной кости с опорой на Манджушри и рассматриваемое автором гадание посредством Авалокитешвары. Тибетский текст написан черной тушью на русской бумаге фабрики наследников Сумкина № 7, на что указывает филигрань на стр. 5b. На лицевой стороне первого листа тибетскими буквами написаны слоги om āḥ hūṃ. Гадание посредством Авалокитешвары начинается на странице $3 b$. Текст состоит из 8 листов, размер рукописи $21,5 \times 7,5$ см. За ним следует тибетский текст «Дхарани Манджушри, увеличивающего интеллект» (тиб. 'phags pa 'jam dpal gyi shes rab dang blo "phel ba zhes bya ba'i gzungs, санскр. āryamañjuśrī prajnā buddhivardhananāmadhāraṇī), входящеe в Кангьюр и в Сунгдуй (тиб. gzungs 'dus)'

Над слогами мантры «от̣ ma ṇi pad me hūmฺ» в объяснениях результатов гаданий в каждом случае синей шариковой ручкой написаны тибетские цифры от одного до шести, обозначающие количество глазков на сторонах гадальной кости, в случае, если используется кость с глазками, а не нанесенными на нее слогами мантры.

\section{Гадальные кости}

В распоряжении Улзийбат Амарбаясгалана, хозяина рукописи, также оказалась гадальная кость, использовавшаяся для этого гадания. Она представлена на фото 1. Расположение тибетских букв шестислоговой мантры «от̣ ma ṇi pad me hūṃ» продемонстрировано на рис. 1. В тексте не говорится о том, из какого материала должна быть сделана кость для гадания, в отличие от, например, «Способа гадания на гадальных костях посредством Палден Магсор Гьялмо „Ключ, отворяющий важные моменты устных наставлений для [достижения] абсолютного ясновидения“"» (тиб. dpal ldan dmag zor rgyal mo'i sho mo 'debs tshul mngon shes mthar thug gi man ngag gnad kyi dbye ba'i lde mig), автором которого является некий Джигме (тиб. 'jigs med). В этом тексте гово-

\footnotetext{
${ }^{6}$ См., напр.: [Музраева 2018: 75].
}

рится, что три кости или кубика для гадания должны быть сделаны из черного дерева с шипами или сандала. В тексте «Метод совершения гадания Единственной матери Владычицы мира желаний на гадательной кости» (тиб. ma gcig 'dod pa khams kyi dbang mo'i sho mo 'debs tshul), автором которой является III Панчен-лама Лобсанг Палден Еше (тиб. blo bzang dpal ldan ye shes, 1738-1780) сказано, что кубическая кость для гадания должна быть сделана из морской раковины или слоновой кости.

Расположение букв мантры «от̣ ma ṇi pad me hūmฺ» на шести гранях кости следующее: от̣ размещается сверху, hūṃ - снизу, ma ṇi pad me - по четырем граням между верхней и нижней гранями.

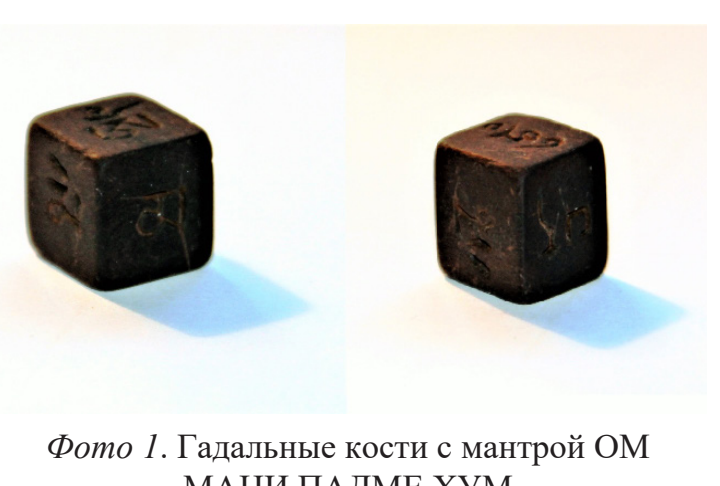
МАНИ ПАДМЕ ХУМ

[Photo 1. Divination dice with engraved syllables of Avalokiteshvara's mantra (OM MANI PADME HUM)]

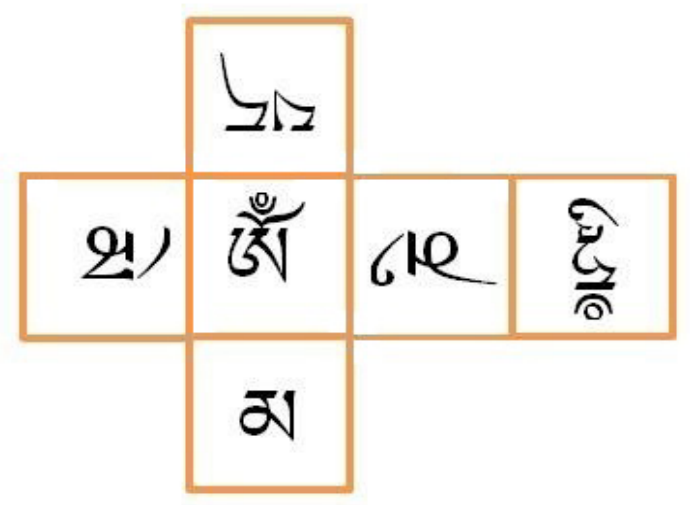

Puc. 1. Диаграмма, демонстрирующая расположение слогов мантры на гадальной кости

[Fig. 1. Diagram illustrating the layout of syllables on the divination dice] 


\section{Процедура гадания}

Перед тем как приступить к гаданию, необходимо обратиться к Авалокитешваре с молитвой, а затем как можно больше повторить мантру Авалокитешвары «ом ma ṇi pad me hūṃ». После этого необходимо подуть на кость для гадания и бросить ее. В некоторых текстах говорится, что кость бросается на специальный войлочный коврик для гадальной кости (тиб. sho gdan). В данном тексте такое требование отсутствует.

Объяснение результатов несколько отличается в ойратском и тибетском текстах. Самое заметное различие заключается в том, что в ойратском тексте объяснения для больного человека и скота объединены в одном отрывке под заголовком объяснения результата гадания для каждого из шести слогов. В тексте на тибетском эти два подраздела для больного человека и скота вынесены отдельно, образуя по два раздела под повторяющимися заголовками каждого из шести слогов мантры «ом̣ ma ṇi pad me hūmฺ». Также в некоторых случаях объяснения результата гадания, выпавшего на один и тот же слог, даны прямо противоположные интерпретации. Например, в тибетском тексте сказано: «Если выпал НИ - заслуги всегда будут преумножаться. Задуманные дела исполнятся. Если столкнешься с врагом, сам будешь побежден ${ }^{7} »$ [НА КалмНЦ РАН. Ф. 8. Оп. 3. Д. 181]. В ойратском тексте аналогичный фрагмент звучит следующим образом: «Если выпал НИ - продолжительность жизни и благополучие преумножатся. Все задуманные дела исполнятся. Если отправишься войной, то победишь». Мы предполагаем, что такое различие возникло вследствие неверного перевода с монгольского/ойратского на тибетский язык. О том, каков был язык оригинала этого гадания, будет сказано ниже.

Самым заметным отличием ойратского текста от тибетского являются объяснения результатов гадания, совершаемого трижды подряд. Традиционно три гадания подряд совершались для того, чтобы удостовериться в верности полученных результатов. Этот раздел отсутствует в ойратском тексте. Можно предположить, что он был скомпилирован после перевода на тибетский язык или добавлен из другого текста по гаданию.

${ }^{7}$ Тиб. thab [`thab] rtsod na rang bcom.
После объяснения результатов гадания в каждом из разделов говорится о том, какие ритуалы необходимо совершить, чтобы исправить ситуацию. Таким образом, как и многие другие гадания, текст этого гадания состоит из двух частей: объяснение результата гадания, объяснение методов устранения неблагоприятных факторов, о которых говорит гадание.

Ритуалы, указываемые в текстах гадания

Многие из ритуальных текстов, называемых в этом гадании, включены в «Собрание дхарани», или по-тибетски Сунгдуй: «Ушнишавиджая», «Белозонтичная», «Сутра долгой жизни», «Чернозонтичная», «Раскаяние из „Сутры Золотистого света“"» и т. д. Иногда чтение всего «Собрания дхарани» используется как ритуал. Часто встречается предсказание о необходимости совершить подношение «Тринадцати воскурений „санг“». «Тринадцать воскурений» (тиб. bsangs bcu gsum) - крайне популярный в Монголии текст подношения воскурения дымом, которое по-тибетски называется «санг» (тиб. bsangs). В Монголии его читают как на тибетском, так и на монгольском языке. Помимо других известных и популярных ритуалов, таких как «Подношение водных торма» (тиб. chu gtor), торма четырех элементов (тиб. 'byung bzhi'i gtor ma), ритуал усиления «коня ветра» (ритуал удачи), четырех сотен подношений (тиб. brgya bzhi), ритуал призывания удачи и защиты (тиб. g.yang skyabs), ритуал призывания удачи (тиб. phyu [phywa] len) и др., встречаются и более редкие ритуалы. Например, это «ритуал умиротворения болезней, преждевременной смерти и духов умерших» (тиб. na shi dur gsum bcos, сокращ. от na shi dur gsum gyi bcos thabs). В виде ритуалов также предписывается совершение определенных добродетельных действий, призванных устранить препятствия и проблемы, возникающие на жизненном пути верующего. Это создание цаца (тиб. tsha tsha) или глиняных пирамидок, в виде ступ, в глину для создания которых часто добавляли пепел от кремации человека, для того чтобы обеспечить ему хорошее рождение. В тибетском тексте говорится о получении «разрешения» на практику божества (тиб. rjes gnang, санс- 
кр. anujñā), что тоже считалось полезным для устранения препятствий. Ойратский текст использует термин abušiq [=abišiq] (от санскр. abhișeka 'посвящение'). Разрешение, или ануджня на санскрите (тиб. rjes gnang, саснкр. anujñ̄ā), - так называется ритуал, менее сложный, чем ритуал посвящения (тиб. dbang, санскр. abhișeka), который дает право выполнять определенные практики в рамках определенного цикла тантрических наставлений, включая йогу божества (тиб. lha'i rnal 'byor, санскр. devatā-yoga) и чтение мантры, но исключая действия по обучению и дарованию

\section{Транслитерация ойратского текста}

Условные знаки, используемые в транслитерации: 1) круглые скобки ( ) заключают в себе межстрочные вставки в тексте; 2) квадратные скобки [] заключают в себе графему или лексему, пропущенную в тексте и восстановленную

(1a) nidü-bēr üzeqči-yin šō talbixü südür orošiboi::

(1b) na[mo] lo[ke] šo ra ya: arban züq үü̈rban| cagiyin burxan bügüde kigēd: bodhi $\mid=$ sadv noyoüdtu mürgümüi: amitan bü| =küni eneren nigüülesküi sedkil| tögüsüqsen bögōo [=bögōd] ene tölgei-gi| adistidalen [=adistidlan] soyirxo: yambar čilen| sayin moü-gi xoyor ügei il $\gamma$ an soyir|=xọ: nidü-bēr

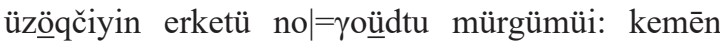

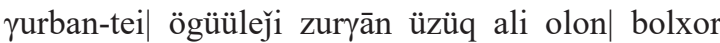
dabtuǰi šōgi ülēgēd ünen| züreken-ēce zalbạr či [=zalbirči] šibaššed tal|=bin üyilēed::

om-du buübāsu maši| sayin: burxan sakoüsun ibēkü sanaq|=san kereq bütükü: cereqtü mordobāsu| dayini darxü: balaqdiyin üyiledü öl|=zöyitei: bere abxülā buyan arbīd|=xü: kerüül temecelni daraxü: yabudal|du yabuxulā mör bütēkü: ebečin-dụ bögōsü edegekü kilbạr: šiltān| inu zöün ömöne [=ömüne]-ēce xoǰi $\gamma$ or kigēd ba|=roun-dan menggetei kümüni arki buyu xara| sabutai-ēce qai bolba: nirayil-bāsu|

(2a) burxan šütēn takibāsü sayin: alduüll| zabxuül bolbāsu suruq sonosxu: koko [=kökö]| debeltei kümün-ēce edēsü xōro suruq| sonosxu: temēn bolbāsü xamar seterkei| buyu morin bolbāsü šīri

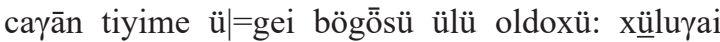
abxula| tübüq [=tübeq] bartai oldoxu: ene tölge

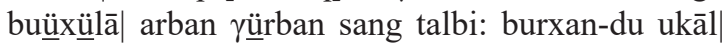
örgüji üyiledkülē sayin::

ma-du| buäbāsu burxan saküüsun ülü talxu:| dayisünn-lügē učirbāsu zoboxu: balyadi-| yin üyile посвящений. Право совершать последние дает заключительная часть абхишеки, или посвящения наставника (тиб. slob dpon, санскр. ācārya) [Buswell, Lopez 2014: 51]. Получив такое разрешение, верующий совершал практику этого божества, веря, что повторение его мантры поможет справиться с неблагоприятной ситуацией.

Несмотря на все ошибки, тибетский текст часто помогает понять неясные места ойратского, поэтому переводы обоих текстов помещены нами в статье параллельно, чтобы проиллюстрировать различия между ними.

как несомненная; 3) квадратные скобки со знаком равенства [=] заключают в себе классическое написание предшествующего слова; 4) знак равенства = является переносом части лексемы на следующую строку; 5) вертикальная черта | обозначает конец строки.

türgen ülü bütükü: bere abxulā| gem bolxu: kerüül temecel bolbāsu zobo|=xu: yabudaldu yabuxülā sedkil ülü amur|=xu [=amuraxu]: ebečin-dü udān edegekü: saküüsun| ni xorlo [:] klusuyin xorlo: yabüdali-yin kümün|-ēce yai bolbo: nirayilbāsu sedkil ülü| amuraxu: aldoül bolbāsu zobobačü suruq| sonosxu ügei bögősü eberēn irekü: ba|=roün ömöne| xadtai yazar bui: ese oldo|=bāsu güremtei: ene tölge buüxulā dundu:| burxan šütēndü takil örgö: klusūd taki:| kelen aman utul sudur ungšiül: kišiq dallya [=dalal $\gamma-a]$ ab saca talbibāsu sayin:: ::|

(2b) ni-dü buübāsu nasun-du buyan arbid|=xu: sanaqsan kereq bükün bütükü: dayisun|-lügē učirbāsu daraxü: ed geretü [=ger-tü] xurābā|=su arbidaxu bolxu: bere abxülā zokixü sayin:| keroül temecel öböröyin zokildaxu: yabudal|-du yabuxülāā amur irekü: ebečin-dü gem| ügei: keroül buzariyin gem buzar idēn bu|=zar xübcasun-ēce bolba: aldubāsu oll=xu: xüluyai abxülā xolo ügei suruq| sonosxü: morin abāsu soül axür öbö=röyin oldoxü: kümün abči ireǰi öq $=$ =kü: baroün xoro yol yazar bui üker| bolbāsu bü xai[:] öböröyin irekü: morin bol|=bāsu zöün xōro bui: erelj̄i kümün nüür|=tēn mengetei koko [=kökö] debeltei kümün kelekü:| xoyin [=xonin] bolbāsu dariü oldoxu zöün $x \bar{o} \mid=r o$ үü̈rban ger kümün bariqsan bui: xoyin [=xonin] bö|=gő̄sü nidün soxor bui: nirayilbāsu ed| buyan arbijixu: ene tölge buuxulā| burxan šütēn taki nasuni sudur ungši: zulu küji örgökülē sayin::

pad-du [=tu] buübāsu burxan saköüsu| šamduǰi taki: edtü $\gamma$ arši bolxu 
(3a) sanān zobonixu ebečindụ türgen ü|=lü edegekü: keröül temecel bolbāsu sed|=kil ülü amurxü:

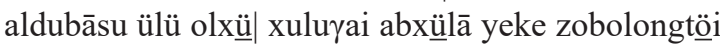
ö|=ni udān suruq sonosxü̈yin tödüi: ba $\mid=$ roün züqtü xān noyon kümüni maldu bui:| morin bögösü nidündēn gemtei xayaraxai| deltei: blama buyu koko

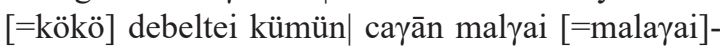
tai kümün kelekü: üker bol|=bāsu xoyitü züqtü kümün bariqsan xoyor| xonogiyin soüldü oldoxü: ese ol $\mid=$ dobāsu xara šükürtü ungši: morin bol $\mid=b a ̄ s u$ xoyitu züqtü doqšsin modun bu|yu modutai yazar bui: xonin bolbāsu| ömüne züqtü kümüni maldu bui: türgen| xai: belbesen buyu caүān noxoi daxüüul|=sun kümün kelekü: ene tölge buübāsu:| tengger klusud

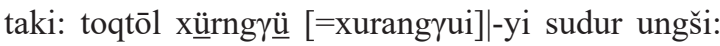
suburyü bosxo: abu|=šiq [=abišiq] abxu bolbāsu sayin::

me-dü| buüxülā: üyile bükün-dü moü: saköüsun| orkiqsan örbör-tü [=öbör-tü] ebečin taxal bolxü:| dayisün-lügē učirxülā nasun axür: ed| gertü xürāxü̈lā öböröyin baraqdaxü bere| abxülā ülü zoxixu: ebečindü $\gamma$ ašoün|

(3b) zobolong bui: šiltān inu moü idē bur|=ta xübcasun ba ulān xara ed-ēce bol|=boi:: nirayilbāsu moü: xulu\}ai abxülā ü|=lü oldoxü: töüni xara alaq moritei ci|=ken-dēn menggetei kümün buyu cayān debeltei| kümün kelekü: morin bögōsü zöün zügtü

\section{Транслитерация тибетского текста}

Условные знаки, используемые в транслитерации: 1) круглые скобки ( ) заключают в себе межстрочные вставки в тексте; 2) квадратные скобки [] заключают в себе графему или лексему, про-

(3b) na mo gu ru lo ki $[=\mathrm{ke}]$ shwa ra $[=\mathrm{rA}]$ ya/ phyogs bcu dus gsum gyi sangs rgyas| byang sems thams cad la phyag 'tshal lo/ sems can thams cad| la snying rje[s] byin gyis brlab tu gsol/ gang bzang ngan gnyis kyi cal coll ma byed/ bsal [=gsal] bar ston[/] spyan ras gzigs la phyag 'tshal lo//

(4a) om ma ṇi pad me hūm/ yi ge drug [pa] bzlas sho [la] btab// om babs na/ shin tu bzang/ lha bsrung [=srung mas] bsam don grub [=sgrub]/ dmag [tu] 'gro| na dgra ’joms/ mkhar langs na bkra shis so/ bag ma len [na] bsod nams| spel [='phel]/ 'thab rtsod na [dgra] bcom/ mgron `gro na lam mthun/ nad [pa yin] na gsos $\mid$ par sla/ rkyen ni bshes gnyen gyi mi gtsang zas yod/ btsas na lha gsol| na bzang/ bar stor [yin] na gtam thos/ tshom [=chom] rkun [gyis] len na/ sdug chung thob/|

(4b) mo 'di bab na la nye bsangs bcu gsum bzhag lha la khrus bya [na] bzang ngo/// ma bab na/ gang bya na `bring po/ chos skyong ma dgongs par gyur/| ö|=böriyin maldu bui: caүān debeltei kümün kelekü:| üker bolbāsu baroün xōron xai: xara| moritei kümün kelekü: ene tölgē buüxxülā| arban rürban sang talbi takil örgö: caca gürüm kelegē [=kele] aman tasul nasuni| tō $\gamma$ or abušiq [=abišiq] ab: buyan-du šamdubā $\mid=$ su sayin:: ::

hǖm-du buüxülā| burxan saköüsun ibēkü ali sanaqsan| kereq bütükü: idēn ed yeke-dü arbid|=xu:

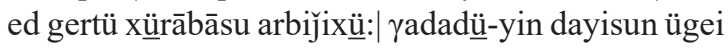
bere abxüulā buyan arbidxụ̈: yabudaldu yabuxülā ol|=zo olxü: ebedbēsü edegekü: šiltān| inu kišiqtei mal yaruqsan kigēd:| kišigiyin ed buzar boluqsan buyu:| moü zöüden oro\}son-ēce gem bolbo|=yi [=bolboi]: keroül temecel bolbāsu öböröyin|

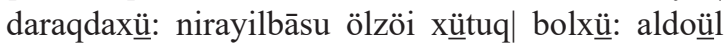
zabxüül xülluyai|

(4a) xüdal bolbāsu suruq sonosxü̈:| temēn bolbāsu zöün ömüne noyon kü|=mün kelekü: morin bolbāsu öböröyin| sürüqqtu bui: ereǰi ülü öböröyin| irekü: ese

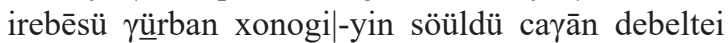
kümün ke|=lekü: üker bolbāsu čono buyu xu|=luyai ideqsen: bitikei xai: ene| tölgē buübāsu maši: sayin kiy=mori delgeröül: klusud taki|=bāsü sayin::

(4a) sarva mangghalam [=manggalam] $]:$ om ma ṇi pad me hǖm::

пущенную в тексте и восстановленную как несомненная; 3) квадратные скобки со знаком равенства [=] заключают в себе классическое написание предшествующего слова; 4) знак равенства = - перенос части лексемы на следующую строку; 5) вертикальная черта | обозначает конец строки.

dgra phrad na sdug [/] (dgra phrad na sa) khyim ( bab na) langs na myur du mi ’grub// bag [ma] gtong len byas na nyes pa byung/ 'thab rtsod na sdug/ mgron byas [na]| sems mi bte`o [=bde`o]/ nad yin na gso bar yun ring/ chos skyong khros// klu 'i gdon/ mgron mi nas yod/ btsas na sems mi bde byung/ bor|

(5a) na sdug kyang gtam thos/ chos [=chom] rkun len na ma rnyed[/] mo 'di babs na| 'bring ngo/ lha la mchod [pa] phul/ klu'i rgyal po la mchod pa bya/ kha smras| chod/ phyu [phywa] len/ sa ts+tsha btab na bzang/ ṇi 'bab na rtag tu bsod nams| 'phel/ bsam don grub/ dgra 'phrad na rang bcom/ nor khyim [du] `dus [bsdus]| na `phel bar 'gyur/ bag ma [gtong] len byed na mthun bzang/ 'thab rtsod na rang| mthun/ mgron [yin] na bde mo [=po] yang [yong]/ nad [pa yin] na skyon med/ 'thab 'khrugs|

(5b) sam mi gtsang pa ' $\mathrm{i}$ zas dang gos rnyed [=rnying] blang yod/ bor stor [yin] na ma rnyed/ chom| rkun 
thag ring ma yin gtam thos/ btsas na bsod nam che/ mo `di 'bab| na lha rten[/] tshe mto [=mdo] 'don/ lha khrus bya/ mar me bdug spos phul na bzang/| pad `bab na/ chos skyong gsol mchod la `bad/ god kha nor zad yong| sdug blngal [=bsngal] byung/ mi nor nad na `dre `ong [='dres gnod]/ btsas na nor zad chung/ 'thab| rtsod na sems mi bde/ bor na ni rnyed/ chom rkun [yin] na yun ring du gtam|

(6a) thos tsam/gzungs `dus `don/mo `di `bab na| lha klu i [klu] mchod/ bzlog gtor dang sa tsa+tsha gtab [btab]/ rjes gnad [gnang] len na bzang $\mid$ ngo/ me babs na/ gang las [la`ang] ngan/ bsrung [mas] bor [/] lha rang du nyes/ dgra| 'phrad na tshe thung/ nor khyim [du] 'dus [bsdus] na rang zad/ btsas na ngan 'gro/ mgron [yin]| na sdug dang mya ngan ’ong/ rkyen ni mi gtsang zas dang gos dmar nag rdzas| nas yod (yong?)/ rkun [mas] blang na ma thob/ mo `di 'bab na la nye bcu gsum sangs [bsang]|

(6b) btab/ sa tsa+tsha mchod [pa] phul/ rim gro bya/ lo grangs rjes gnang len[/]| dge sbyor la `bad/ btsas na bkra shis/ bor [na] dang [rang] bzang ngo/l hūm `bab na/ lha dang chos skyob [skyong] skyabs/ bsam don grub/ zas nor 'phel/| tshe nor khyim [du] 'dus [bsdus] na spel ['phel] yod [yong]/ bag ma len na bsod nams 'phel// phyi dgra med/ mgron na rnyed [pa] thob/ nad [pa yin] na (g) gzo [gso] bar sla/ rkyen ni phyags [=phyugs] phywa phyi [phyir]| gtang/ g.yang gi nor snod la grib byung `dug/ rmi lam ngan pa las rtog|

(7a) pa las 'ong/ thab ['thab] rtsod na rang bcom/ chom rkun [gyis] len na| gtam thos/ mo 'di 'bad ['bab] na shin tu bzang ngo/

om 'bab na nad myur du gso// bar chad ni byang shar nas `ong ba'i rtags mi nas nag po snod zas 'dug/ zhag| gsum la gso/ gser `od bshags pa rgya [=brgya] rtsa brgyad bya/ grib sel bya// spyar [spyir] kha smras yod [yong]/

ma `bab na/ nad pa rjes bzang gi yin/ ma mo`i| gdon/ lha mo i gtor ma rgyob/ gtsug tor nag mo/ gdugs dkar gsu [=gsum]|

(7b) 'don nas/ grib sel bya/ spyir yin na rdzas nag po gto gtong bya/

ni `bab na// nad [pa] la lho nas 'ong ba'i bar chad yin/ lham [=lho] ma [=nas] ma [=mi] mtshon cha'i yong/ spyir bsangs| bcu gsum gtab [gtang]/ gzungs 'dus 'don/ klu’i mchod [pa] [sa] tsa+tsha btab/ mo 'di phugs| su ngan no/

pad 'bab na/ nad [pa] la myur [du] skur [sku] rim bya/ sa bdag gi[s] gnod[/] na shi| dur gsum bcos/ rdo rje rnam `joms stong tshar chu gtor btab na bzang ngo/l

me 'bab na/ nad la lha'i gdon yin/ bskang bshags (su) gang mang bya/ gdug [gdugs]|

(8a) dkar gyi bzlog bsgyur `don/ spyir god kha `ong/ yum `don| na bzang ngo/

hūm 'bab na/ nad [pa] la zhing [ring] gi `di yin/ rdzas sngon nag rdzas yod/| ban+de bon po`i rdzas yod [/] me lha mchod/phyag rdor 'don/ 'byung bzhi ['i] gtor ma| gtang/ rlung rta dar [dang] klu mchod bsang/ [sa] tsa+tsha btab [na] bzang ngo/

om `bab na// bor stor na byang shar nas gos nag mi nag [nas] gtam thos/ rnga mong dang rta yin [na]| rtags yod na [rnyed]/ rtags med na ma rnyed do/ ma 'bab na/ stor [lhor] shar lho brags [brag]|

(8b) ngam [gam] gos dmar mi nas gtam thos/ yang na rang yod [/] ma rnyed na sku rim bya//

nii bab na/ rngam [rnga] mong de yin na/ rtags yod na ryed/ lho nub ngam [bam] grogs| la `dug/ rta yin na nub byang du yod/ glang [yin] na rang [la] yod/ lug nub byang dul mi [mis] zin pa`o/

pad 'bab na/ lho phyogs su dpon po`i phyugs la yod/ ban+de mi| nas gtam thos/ rnga mong byang du shing (la) sa la yod/ mi nas thos/ glang [yin] na| nub phyogs na mi zin zhag gnyis la thob/ ma thob na gtsug tor nag mo `don//

(9a) lug [yin] na shar du dpon po i phyugs [la] yod/ thag rim [ring] ma yin khyi| dkar 'brang [pa`i] mi nas gtam thos `dug/

me 'bab na/ rnga mong [yin] na byang shar du| rnam [rna la] rna gas [rme nag] mis zin `dug/ rta [yin] na byang du rang gi phyugs du [su] yod/ gos dkar| gyi mi nas gtam thos/

hūm `bab na/ rnga mong [yin] na byang shar la yod/ rta yin| na rang 'ong [/] ma `ong na zhag gsum la gos dkar mi nag po gzhon [bzhon] nas 'khyer 'dug/| bar chad ni byang shar nas 'ong ba'i snod nag [nas] zas 'dug/ gser 'od 'don//

(9b) grib sel bya o/ mo 'di ni spyan ras gzigs gyi shel dkar mi [me] long zhes| pa`o/

gsum ka la yang bzang po byung na/ gzhi bzang/ phyi dgra med/| bor stor rnyed/ [dkon mchog] gsum la mchod [pa] 'bul/

gsum ngan na/ spyir kun tu ngan/| nyi khri brgyad stong pa brgya bzhi bya/

dang po gcig bzang phyi ma gnyis dman [ngan na] khang| khyim `bub dang dgra med bzang/ bag [ma] len na bde skyed [skyid]/ bor stor [yin] na rnyed/| thos pa [bros na] zin/ nad pa sman phrad ['phrod] shin tu bzang [/] mo 'di kun tu bzang/ [dkon mchog] gsums [gsum]

(10a) la mchod pa ‘phul/ snga phyi bzang la bar [ma] nang [ngan] na// gzhi sogs gang gi las la bzang/ bor rnyed/ g.yang skyabs len/| lha khrus bya/ snga gnyis bzang zhing phyi gcig ngan [na]/ bya ba kun| la ngan par bshad/

phyi ma gcig bzang snga ma gnyis| ngan [na]/ gzhi mo nad mo las la mo `di 'bring/| bor stor ma rnyed [/] rkun ma zin/ dang po gcig ngan la phyi|

(10b) ma gnyis bzan [bzang] na/ dgra cha la dgra ngo/ grogs| cha la grags [grogs] med/ khang khyim 'bub pa la `bring/| khang khyim 'bub [na] 'bring/ ma `bor na ma rnyed [/] mo `di kun tu `bring/ lha la ba sangs [=bsangs] btab/| khrus bya/ gzungs [bsdus] 'don [na] bzang// 


\section{Перевод на русский язык}

\begin{tabular}{|c|c|}
\hline Перевод ойратского текста & Перевод тибетского текста \\
\hline $\begin{array}{l}\text { (1a) Сутра9 «Гадание Авалокитешвары } \\
\text { посредством гадальной кости» } \\
\text { (2а) НАМО ЛОКЕШВАРАЯ! }\end{array}$ & (3b) НАМО ЛОКЕШВАРАЯ! \\
\hline $\begin{array}{l}\text { Кланяюсь пред всеми буддами и бодхисаттвами деся- } \\
\text { ти сторон света и трех времен! } \\
\text { «Прошу вас, все, кто преисполнен сострадательного } \\
\text { стремления ко всем живым существам, благословите } \\
\text { это гадание }{ }^{10 !} \text { Что бы то ни было, прошу вас, прямо } \\
\text { разделите хорошее и плохое! Пред Владыкой Авало- } \\
\text { китешварой со свитой склоняюсь!» - произнеся так } \\
\text { три раза, повторяй как можно больше шесть слогов } \\
\text { (мантры ОМ МАНИ ПАД МЕ ХУМ). Затем подуй } \\
\text { на кость для гадания и искренне обратись с мольбой. } \\
\text { Обратившись к божеству, брось гадальную кость. }\end{array}$ & $\begin{array}{l}\text { Кланяюсь пред всеми буддами и бодхисат- } \\
\text { твами десяти сторон света и трех времен! } \\
\text { «Прошу, благословите всех живых существ } \\
\text { состраданием! Оба - хорошее и плохое, не } \\
\text { произнося бессмысленных слов, ясно пока- } \\
\text { жите! Пред Авалокитешварой склоняюсь!» } \\
\text { (4a) Повторив шесть слогов [мантры] ОМ } \\
\text { МАНИ ПАД МЕ ХУМ, брось кость [для } \\
\text { гадания]. }\end{array}$ \\
\hline $\begin{array}{l}\text { Если выпал ОМ - очень хорошо. Будды и защит- } \\
\text { ники благоволят. Задуманное дело исполнится. Если } \\
\text { отправишься войной, то победишь врагов. Строитель- } \\
\text { ные работы сложатся благополучно. Если возьмешь } \\
\text { невесту, благополучие преумножится. В конфликте } \\
\text { победишь. Если отправишься по делам, обретешь } \\
\text { благополучие. Больной легко излечится. Причина } \\
\text { несчастья произошла из-за водки или черного сосуда } \\
\text { лысого человека с юго-востока и человека с родин- } \\
\text { кой с запада. Если [спрашиваешь о] родах - хорошо } \\
\text { бы совершить подношение образам будд. Если слу- } \\
\text { чилась потеря, скоро услышишь новость о [потеря- } \\
\text { ном]. Услышишь новость от человека в синей одежде } \\
\text { издалека. Если [потерялся] верблюд, но не верблюд с } \\
\text { порванным носом, то не найдется, если лошадь, но не } \\
\text { белой масти, то не найдется. Украденное найдешь с } \\
\text { малыми трудностями. Если выпало это гадание, со- } \\
\text { верши подношение «Тринадцати сангов». Хорошо со- } \\
\text { вершить подношение омовения буддам. }\end{array}$ & $\begin{array}{l}\text { Если выпал ОМ - очень хорошо. Боги } \\
\text { и защитники исполнят задуманное дело. } \\
\text { Если отправишься войной, то победишь } \\
\text { врагов. Если возведешь дом, будет благо- } \\
\text { получие. Если возьмешь невесту, благо- } \\
\text { получие преумножится. Если вступишь в } \\
\text { конфликт, победишь. Если отправишься } \\
\text { в гости, дорога будет благоприятна. Боль- } \\
\text { ной легко излечится. Причина несчастья } \\
\text { произошла из-за нечистой еды друга. Если } \\
\text { [спрашиваешь о] родах - хорошо бы со- } \\
\text { вершить подношение божествам. Если слу- } \\
\text { чилась потеря, скоро услышишь новость о } \\
\text { [потерянном]. Забранное ворами и грабите- } \\
\text { лями найдешь с малыми трудностями. } \\
\text { (4b) Если выпало это гадание, соверши ря- } \\
\text { дом с перевалом подношение «Тринадцати } \\
\text { сангов». Хорошо совершить подношение } \\
\text { омовения божествам. }\end{array}$ \\
\hline $\begin{array}{l}\text { Если выпал МА - защитники не довольны. Если } \\
\text { отправишься войной, то будешь горевать. Строитель- } \\
\text { ные работы не исполняться быстро. Если возьмешь } \\
\text { невесту, будет неудача. Если встрянешь в конфликт, } \\
\text { будешь горевать. Если отправишься по делам, душа не } \\
\text { найдет удовлетворения. Больной излечится медленно. } \\
\text { Защитники и наги причиняют вред. От человека, с кем } \\
\text { имеешь дело, будет несчастье. Если [спрашиваешь о] } \\
\text { родах - душа не найдет удовлетворения. Если случи- } \\
\text { лась потеря, хотя и будет неудача, если не услышишь } \\
\text { новостей, надеется само. [Потерянное] находится в } \\
\text { юго-западном направлении, скалистом месте. Если не } \\
\text { найдется, сделай ритуалы. Если выпало это гадание, }\end{array}$ & $\begin{array}{l}\text { Если выпал МА - что бы ни делал, [га- } \\
\text { дание] среднее. Защитники дхармы не до- } \\
\text { вольны. Если столкнёшься с врагами, то } \\
\text { будешь горевать. Если возводишь дом, то } \\
\text { быстро это не произойдет. Если берешь или } \\
\text { отдаешь невесту, будет беда. Если встря- } \\
\text { нешь в конфликт, будешь горевать. Если } \\
\text { отправишься в гости, ум не найдет сча- } \\
\text { стья. Больной будет выздоравливать долго. } \\
\text { Защитники дхармы разгневаны. [Вредят] } \\
\text { демоны нагов. От гостя [будет несчастье]. } \\
\text { Если [спрашиваешь о] родах - будешь не- } \\
\text { счастлив. Если случилась потеря, }\end{array}$ \\
\hline
\end{tabular}

${ }^{9}$ Под сутрой в ойратском языке часто подразумевается любой буддийский текст.
${ }^{10} \mathrm{~B}$ тибетском тексте: «Прошу, благословите всех живых существ состраданием». 

будд. Соверши подношение нагам. Читай «Сутру, отсекающую сплетни». Соверши призывание удачи. Будет хорошо совершить подношение санга. то [ситуация] средняя. Соверши подношение образам

(5a) хотя и будут трудности, услышишь новости. Забранное ворами и грабителями не найдется. Если выпало это гадание, то [ситуация] средняя. Соверши подношение божествам. Соверши подношение царю нагов. Отсеки сплетни. Соверши призывание удачи. Будет хорошо сделать цаца.

(2b) Если выпал НИ - продолжительность жизни и благополучие преумножатся. Все задуманные дела исполнятся. Если отправишься войной, то победишь. Если будешь собирать имущество дома, оно приумножится. Если возьмешь невесту, она подойдет. Если вступишь в конфликт, ты осилишь. Если отправишься по делам, легко получится. Для больной нет опасности. Конфликт, болезнь из-за загрязнения возникли вследствие грязной еды и нечистой одежды. Потерянное найдется. Если своровано, то скоро услышишь новость из недалекого места. Если [потерялся] конь, вскоре сам найдется, его приведут и отдадут обратно люди. Он на западе в месте, где есть навоз, если же его там нет, то не ищи, придет сам. Если [потерялась] лошадь, она находится на северо-западе. Человек, который нашел ее - рябой и с родинкой, расскажет человек в синей одежде. Если [потерялась] овца, вскоре найдется. На северо-западе люди из трех кибиток поймали ее. Если [потерялась] овца, она у слепого. Если [спрашиваешь о] родах - имущество и благополучие преумножатся. Если выпало это гадание, то соверши подношение образам будд. Читай «Сутру долгой жизни». Будет хорошо, если совершить подношение светильников и благовоний.

Если выпал ПАД - поспеши сделать подношения Если выпал ПАД - усердствуй в поднобуддам и защитникам. Будет убыток имуществу, [3a] сердце будет беспокоиться. Больной быстро не излечится. Если вступишь в конфликт, душа не найдет удовлетворения. Потерянное не найдется. Если своровано, то испытаешь много горя. Если [потерялась] корова, но новости услышишь не скоро. Она находится среди скота могущественного хана, правителя или человека. Если [потерялась] лошадь, о ней расскажет лама с больными глазами и в порванной одежде или человек в синей одежде или человек в белой шапке. Если же не нашлась, то она поймана могущественным человеком на севере, найдется спустя двое суток. Если не найдется, читай «Чернозонтичную». Если [потерялась] лошадь, она находится на севере у могучего одинокого дерева или в лесистой местности. Если [потерялась] овца, она на юге среди скота могущественного человека. Скорее ищи. Расскажет о ней вдова, или человек, за которым следует белая собака. Если выпало это гадание, то соверши подношение божествам и нагам. Читай «Собрание дхарани». Построй ступу. Будет хорошо, если примешь посвящение.
Если выпал НИ - заслуги всегда будут преумножатся. Задуманные дела исполнятся. Если столкнешься с врагом, сам будешь побежден. Если будешь собирать богатство дома, оно приумножится. Если возьмешь невесту, будет согласие, это хорошо. Если вступишь в конфликт, будет благоприятно для тебя. Если отправишься в гости, будет благополучно. Для больной нет опасности. Конфликт [возник]

(5b) из-за того, что взял нечистую еду или старую одежду. Потерянное не найдется. Воры и грабители не [ушли] далеко, скоро услышишь новость. Если [спрашиваешь о] родах - добродетель [будет] велика. Если выпало это гадание, [то соверши подношение] образам божеств. Читай «Сутру долгой жизни». Поднеси омовение божествам. Будет хорошо, если совершить подношение светильников и благовоний.

шениях зашитникам дхармы. Будет убыток имуществу, будет страдание. Если болеют люди и скот, вредят демоны. Если [спрашиваешь о] родах - богатство истощится и уменьшится. Если вступишь в конфликт, ум не найдет удовлетворения. Потерянное не найдется. Потерянное не найдется. Если [вопрос] о ворах и грабителях, по прошествии долгого времени

(6а) едва услышишь новость [об украденном]. Читай «Собрание дхарани». Если выпало это гадание, то соверши подношение божествам и нагам. Сделай ритуал торма, для устранения препятствий, и цаца. Хорошо, если получишь разрешение [на практику божества]. 


\begin{tabular}{|c|c|}
\hline $\begin{array}{l}\text { Если выпал МЕ - плохо для всех действий. Ты, } \\
\text { покинутый защитниками, заболеешь заразной болез- } \\
\text { нью. Если вступишь в конфликт, жизнь будет корот- } \\
\text { кой. Если будешь собирать имущество дома, оно само } \\
\text { иссякнет. Если возьмешь невесту, она не подойдет. } \\
\text { Больной испытает горькие страдания. Причина не- } \\
\text { счастья произошла из-за плохой еды, грязной одеж- } \\
\text { ды и красной или черной вещи. Для родов - плохо. } \\
\text { Украденное не найдется. Расскажет человек на чер- } \\
\text { ной или пестрой лошади с родинками на ушах или } \\
\text { человек в белой одежде. Если [потерялась] лошадь, } \\
\text { она находится на востоке у могущественного чело- } \\
\text { века. Расскажет человек в белой одежде. Если [поте- } \\
\text { рялась] корова, ищи ее на северо-западе. Расскажет } \\
\text { человек на черной лошади. Если выпало это гадание, } \\
\text { то соверши подношение «Тринадцати сангов». Делай } \\
\text { цаца, ритуалы, отсечение сплетен и восстановление } \\
\text { прервавшейся жизни. Прими посвящение. Будет хо- } \\
\text { рошо, если поспешишь с заслугами. }\end{array}$ & $\begin{array}{l}\text { Если выпал МЕ - плохо для любого дей- } \\
\text { ствия. Ты покинут защитниками, божества } \\
\text { недовольны тобой. Если вступишь в кон- } \\
\text { фликт, жизнь будет короткой. Если будешь } \\
\text { собирать имущество дома, оно само иссяк- } \\
\text { нет. Для родов - плохо. Если отправишься } \\
\text { в гости, будут страдание и горе. Причина } \\
\text { несчастья произошла из-за плохой еды, } \\
\text { грязной одежды и красной или черной суб- } \\
\text { станции. Украденное не найдется. Если вы- } \\
\text { пало это гадание, то соверши подношение } \\
\text { «Подношение санга тринадцати» на бли- } \\
\text { жайшем перевале. } \\
\text { (6b) Делай цаца, совершай подношения и } \\
\text { ритуалы. Прими разрешения [на практику } \\
\text { божества], количество которых равно коли-- } \\
\text { честву прожитых лет. Усердствуй в добро- } \\
\text { детели. Если родится [дитя], будет благопо- } \\
\text { лучие. Если утеряна [вещь, то] будет благо. }\end{array}$ \\
\hline $\begin{array}{l}\text { Если выпал ХУМ - Будды и защитники благово- } \\
\text { лят. Все задуманные дела исполнятся. Еда, имуще- } \\
\text { ство и т. д. преумножатся. Если будешь собирать иму- } \\
\text { щество дома, оно преумножится. Во вне врагов нет. } \\
\text { Если возьмешь невесту, то благополучие увеличится. } \\
\text { Если отправишься по делам, обретешь благополучие. } \\
\text { Поломанное восстановится. Причина несчастья прои- } \\
\text { зошла из-за потери скота благополучия, из-за загряз- } \\
\text { нения имущества благополучия и из-за возникнове- } \\
\text { ния дурных снов. Если вступишь в конфликт, то одер- } \\
\text { жишь победу. Если [спрашиваешь о] родах - будет } \\
\text { благополучие и счастье. Вскоре услышишь новости } \\
\text { о потерянном, [3b] украденном и [потерянном из-за] } \\
\text { обмана. Если [потерялся] верблюд, расскажет человек } \\
\text { с юго-востока. Если [потерялась] лошадь, сам полу- } \\
\text { чишь известие. Придет сама, без разыскивания. Если } \\
\text { не придет, по истечение трех суток о ней скажет чело-- } \\
\text { век в белой одежде. Если [потерялась] корова, ее съе- } \\
\text { ли волки или воры. Не ищи. Если выпало это гадание, } \\
\text { то это очень хорошо, увеличивай удачу (развешивай } \\
\text { флажки). Будет хорошо, если также совершишь под- } \\
\text { ношение нагам. } \\
\text { САРВА МАНГАЛАМ. ОМ МАНИ ПАД МЕ ХУМ. } \\
\text { [4а] }\end{array}$ & $\begin{array}{l}\text { Если выпал ХУМ - божества и защит- } \\
\text { ники дхармы защищают. Задуманные дела } \\
\text { исполнятся. Еда и богатства преумножат- } \\
\text { ся. Если будешь собирать жизненную силу } \\
\text { и имущество дома, оно увеличится. Если } \\
\text { возьмешь невесту, то благополучие увели- } \\
\text { чится. Во вне врагов нет. Если отправишь- } \\
\text { ся в гости, обретешь выгоду. Если [гада- } \\
\text { ние] о больном, то он скоро выздоровеет. } \\
\text { Причина [несчастья] произошла из-за по- } \\
\text { тери скота благополучия, из-за загрязнения } \\
\text { сосуда с богатством и из-за возникновения } \\
\text { мыслей из-за } \\
\text { (7а) дурных снов. Если вступишь в кон- } \\
\text { фликт, то будешь побежден. Вскоре услы- }- \\
\text { шишь новости об украденном и ворами и } \\
\text { грабителями. Если выпало это гадание, то } \\
\text { это очень хорошо. увеличивай удачу (раз- } \\
\text { вешивай флажки). }\end{array}$ \\
\hline
\end{tabular}


Если выпал ОМ - болезнь быстро излечится. Причина препятствия возникла из-за еды из черного сосуда [принадлежащего] человеку со знаком с северо-востока. Выздоровеет в течение трех дней. Прочитай сто восемь раз раскаяние из «Золотистого света». [Седлай ритуал] устранения загрязнений. Вообще будут сплетни. Если выпал МА позже больному будет лучше. [Вредят] демоны мамо. Сделай подношение торма [Палден] Лхамо. Прочитав Ушнишавиджаю, Чернозонтичную и Белозонтичную,

(7b) [соверши ритуал] устранения загрязнений. В общем, необходимо сделать откупной ритуал посредством черной субстанции. Если выпал НИ - [оно предвещает] препятствие для больного, приближающееся с юга. С юга [вред придет от] человека с оружием. Сделай подношение «Тринадцати сангов». Читай «Собрание дхарани». Соверши подношение нагам. Делай цаца. Это гадание неблагоприятно в дальней перспективе. Если выпал ПАД - незамедлительно сделай ритуал для больного. Если чинят вред владыки земли, сделай ритуал умиротворения болезней, смерти и духов умерших. Хорошо, если совершишь тысячу подношений Ваджравидаране и поношение водных торма. Если выпал МЕ - больному [чинит вред] демон богов. Сделай как можно больше ритуал умилостивления и раскаяния [пред защитниками]. Читай ритуал

(8a) устранения и обращения в спять препятствий посредством опоры на Белозонтичную Тару. Вообще, будет несчастье. Будет благоприятно, если будешь читать сутры Праджняпарамиты. Если выпал ХУМ - для больного - болезнь будет долгой. [Несчастья происходят изза] синей и черной субстанции, из-за субстанции буддийского монаха или бонца. Делай подношение божеству огня. Читай [ритуал] Ваджрапани. Сделай подношение торма четырех элементов. Будет благоприятно, если сделаешь ритуал усиления «коня верта», подношение нагам и подношение санга, сделаешь цаца. Если выпал ОМ - услышишь новости о потерянном от черного человека в черной одежде с северо-востока. Если это верблюд или конь, если есть знак, найдется, если знака нет - не найдется. Если выпал МА - услышишь новости от человека в красной одежде

(8b) с юго-востока или южной скалы. Или они у тебя самого. Если не найдешь, сделай ритуалы. Если выпал НИ - если это верблюд, если есть знак, то найдется. [Животное] на юго-западе или у друга. Если это лошадь, она на северо-западе. Если это бык, то он на своей [земле]. Если овца, то она схвачена человеком на северо-западе. Если выпал ПАД - [потерянное животное] среди скота чиновника на юге. Услышишь новости от буддийского монаха. Если это верблюд, то он на севере в лесистой местности. Услышишь [новость] от людей. Если это бык, то его схватил человек на западе. Получишь его в течение двух дней. Если не получишь, читай Черную Ушнишу ${ }^{11}$.

${ }^{11}$ Кришна-ушниша-дхарани. 


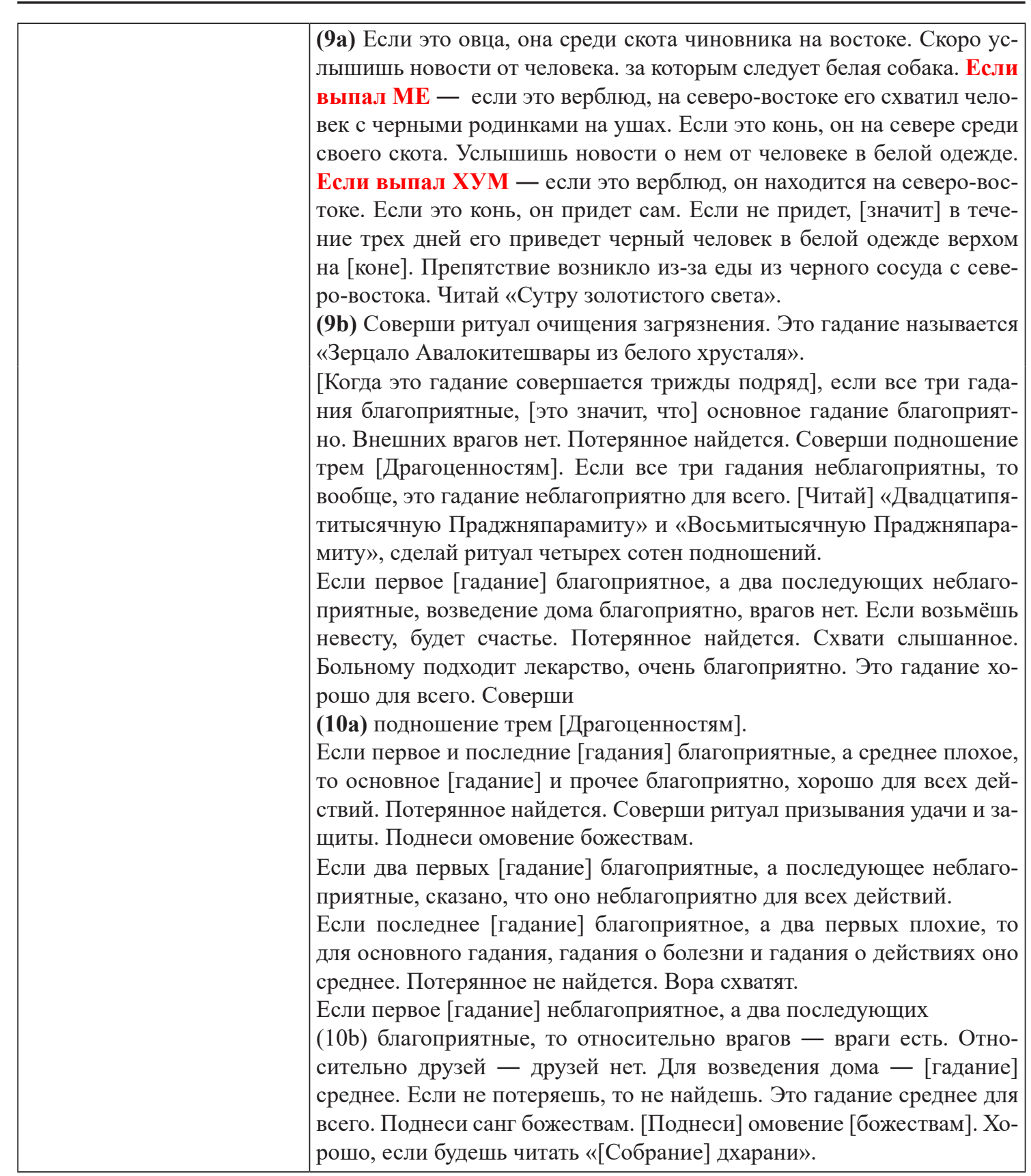

\section{Заключение}

Рассматриваемые здесь ойратский и тибетский тексты гадания посредством Авалокитешвары во многих случаях совпадают, однако между ними достаточно много и различий. Ойратский текст, по всей видимости, был написан человеком, хорошо знавшим ойратский язык, чего нельзя сказать о тибетском тексте, в котором много ошибок, причем ошибок повторяющихся, что указывает на то, что это не описки, а именно ошибки. Например, много неправильно построенных предложений: nad [pa] la zhing [ring] gi 'di yin, rdzas sngon nag rdzas yod. Также много орфографических ошибок, например, bsal [=gsal], grub [=sgrub], spel [='phel], tshom [=chom $]$, bte`o [=bde`o], chos [=chom], mto [=mdo], blngal [=bsngal], phyags $[=$ phyugs $]$; пропущены показатели падежей и другие частицы, которые восстановлены в транслитерации тибетского текста в квадратных скобках: drug [pa], sho [la] btab, rkun [gyis], bag [ma], mgron [yin] na, nad [pa yin] na; в нескольких случаях переписчик дважды переписал одну и ту же фразу: такие фразы помещены в круглые скобки, например, (dgra phrad na sa). 
В тибетском тексте говорится о различных видах вредоносных демонов (тиб. gdon), насылающих болезни и другие беды на людей. Например, демоны богов (тиб. lha'i gdon dang), демоны нагов (тиб. klu'i gdon) и демониц женского пола (тиб. та mo`i gdon). В ойратском же тексте просто говорится, что вред причиняют наги, боги и прочие, опуская названия отдельных видов демонов и духов.

В одном случае в тибетском тексте встречается фраза bsangs bcu gsum bzhag, которая соответствует фразе arban rurban sang talbi в ойратском тексте. Тибетский глагол bzhag 'ставить, класть, размещать' не используется в данном обороте в тибетском языке, в то же время ойратский глагол talbixu, наоборот, часто используется в ойратском эквиваленте этой фразы. Исходя из всех вышеприведенных замечаний о языке тибетского текста, можно предположить, что тибетский текст был переведен с мон-

\section{Источники}

Гадание Авалокитешвары 2011 - Анонимный автор. Nidü-ber üzeqci-yin šō talbixui sudur orošiboi (= «Гадание Авалокитешвары посредством гадальной кости») [электронный pecypc] // Digital Library for International Research. Barintag-06-15. Item \#11364. 13.03.2011. URL: http://www.dlir.org/archive/ orc-exhibit/items/show/collection/7/id/11364 (дата обращения: 21.09.2017).

НА КалмНЦ РАН - Анонимный автор. Безымянный текст гадания посредством Авалокитешвары на тибетском языке. Скан рукописи.

Рукопись. ЭЛК 2 - Анонимный автор. spring ring rgyal por grags pa kwan lo yi'i rno mthong dwangs gsal me long (= «Ясное зерцало острого видения Гуань Юйя, известного как “Длинное облако”»). Электронная личная коллекция.

\section{Sources}

Avalokiteshvara Divination: Untitled Text. Anonymous. Tibetan manuscript. Scanned copy. At: Author's digital collection. (In Tib.)

dpal ldan zhi ba lhas gsungs pa'i sho 'gyed pa'i mo rtsis bstan pa: Clarification of Divination by Throwing the Dice Explained by the Magnificent Shantideva. On: Buddhist Digital Resource Center. In: Kazi S. T. (ed.) Encyclopedia Tibetica. The Collected Works of Bo-don Pan-chen Phyogs-las-rnam-rgyal. Vol. 198. Pp. 191-211. Available at: https:// www.tbrc.org/\#library_work_ViewByOut- гольского или ойратского. Это могло бы объяснить все недостатки тибетского текста, который определённо был составлен тем, кто знал тибетский язык в недостаточной степени. История знает случаи, когда тибетские тексты гаданий являлись переводами с монгольского на тибетский язык. Например, существует гадание, опирающееся на Гэсэра, - «Ясное зерцало острого видения Гуань Юйя, известного как „Длинное облако“» (тиб. spring ring rgyal por grags pa kwan lo yi'i rno mthong dwangs gsal me long) [Рукопись. ЭЛК 2]. Этот текст, обнаруженный в Калимпонге в монастыре Тхарпалинг (тиб. thar pa gling), был переведен с монгольского на тибетский язык, монгольский же перевод был выполнен с китайского храмового гадания Гэсэра или Гуанди. На данный момент невозможно утверждать, что ойратский текст представляет собой перевод с китайского, но такую возможность нельзя исключать.

bo dong - dpal ldan zhi ba lhas gsungs pa'i sho 'gyed pa'i mo rtsis bstan pa (= «Разъяснение гадания посредством бросания костей, объясненное Великолепным Шантидэвой») [электронный ресурс] // Encyclopedia Tibetica: the collected works of Bo-don Pan-chen Phyogs-las-rnam-rgyal / edited by S. T. Kazi. Vol. 198. Pp. 191-211. URL: https:// www.tbrc.org/\#library_work_ViewByOutlineO22103C2O30159\%7CW22103 (дата обращения: 12.08.2020).

mo rtsis - mo rtsis 'jam pa'i dbyangs $(=«$ Гадание Манджушри»). snar thang bstan 'gyur [Нартангский Тенгьюр] [электронный реcypc] // Vol. 211. Pp. 235-247. URL: https:// www.tbrc.org/\#library_work_ViewByOutlineO2DB757121KG75786\%7CW- 22704 (дата обращения: 12.08.2020).

line-O22103C2O30159\%7CW22103 (accessed: August 12, 2020 ). (In Tib.)

mo rtsis 'jam pa'i dbyangs: Manjushri Divination. In: Narthang Tengyur. Vol. 211. Pp. 235247. Available at: https://www.tbrc.org/\#library_work_ViewByOutline-O2DB757121KG75786\%7CW22704 (accessed: August 12, 2020). (In Tib.)

Nidü-ber üzeqci-yin šo talbixui sudur orošiboi: Avalokiteshvara Dice Divination. Anonymous. On: Digital Library for International Research. File ID 'Barintag-06-15'. Item No. 11364. Posted on March 13, 2011. Available at: http:// 
www.dlir.org/archive/orc-exhibit/items/show/ collection/7/id/11364 (accessed: September 21, 2017). (In Oir.)

spring ring rgyal por grags pa kwan lo yi'i rno

\section{Литература}

Buswell, Lopez 2014 - Buswell E. Jr., Lopez S. David Jr. The Princeton Dictionary of Buddhism. New Jersey: Princeton University Press, 2014. XXXII; 1266.

Даваажав, Сугардордж 2012 - Даваажав Д., Сугардордж Д. Монгол зурхайн ухаан, мэргэ төлгийг амьдралд авч хэрэглэх шилдэг аргууд (= Избранные методы применения в жизни монгольской астрологии и гаданий). [Улаанбаатар]: [б. и.], 2012. 192 с.

Мипам 2006 - Мипам Джамгон Ринпоче. Тибетское гадание - мо. М.: Медков С. Б., 2006. $128 \mathrm{c}$.

Митруев, Дугданов 2019 - Митруев Б. Л., Дугданов Ж. Д. Гадание, опирающееся на ламу Цонкапу // Монголоведение. 2020. T. 12. № 1. C. 105-121. DOI: $10.22162 / 2500$ 1523-2020-1-105-121

Митруев 2020 - Митруев Б. Л. Ойратский и тибетский тексты гадания на четках: сравнительно-сопоставительный анализ // Вестник Калмыцкого университета. 2020. № 3(47). C. 70-82.

Музраева 2018 - Музраева Д. Из истории бытования сборника буддийских текстов «Сундуй» у калмыков (на материале коллекции Э. Б. Убушиева, хранящейся в

\section{References}

Buswell E. Jr., Lopez S. David Jr. The Princeton Dictionary of Buddhism. New Jersey: Princeton University Press, 2014. XXXII; 1266 p. (In Eng.)

Davaazhav D., Sugardordzh D. Mongolian Astrology and Divination: Selected Practices. 2012. 192 p. (In Mong.)

Mipham Jamgon Rinpoche. Mo: Tibetan Divination System. Moscow: S. Medkov, 2006. 128 p. (In Russ.)

Mitruev B. L. Comparative analysis of Oirat and Tibetan texts of fortune-telling on prayer beads. Bulletin of Kalmyk University. 2020. No. 3(47). Pp. 70-82. (In Russ.)

Mitruev B. L., Dugdanov Zh. D. Lama Tsongkhapa rosary divination. Mongolian Studies. 2020. Vol. 12. No. 1. Pp. 105-121. (In Russ.) DOI: 10.22162/2500-1523-2020-1-105-121

Muniev B. D. (ed.) Kalmyk-Russian Dictionary. Moscow: Russkiy Yazyk, 1977. 768 p. (In Kalm. and Russ.)

Muzraeva D. N. The gZungs 'dus Buddhist texts collection: excerpts from the history of its mthong dwangs gsal me long: The Clear Mirror of the Sharp Vision of Guan Yu Known as the 'Long Cloud'. Anonymous. Tibetan manuscript. At: Author's digital collection. (In Tib.)

научном архиве КалмНЦ РАН) // Oriental Studies. 2018. T. 11. № 3. C. 68-94.

КРС 1977 - Калмыцко-русский словарь / под ред. Б. Д. Муниева. М.: Русский язык, 1977. $768 \mathrm{c}$.

Опря 1990 - Опря В. Гадание народов мира. М.: Планета, 1990. 350 с.

Сүхбат 2002 - Сүхбат Ш. Монгол үндэсний мэргэ төлөг шинжихүй ёсон (= Способы исследования монгольских традиционных гаданий). Улаанбаатар: [б. и.], 2002. 93 с.

Тодаева 2001 - Тодаева Б. Х. Словарь языка ойратов Синьцзяна (по версиям песен «Джангара» и полевым записям автора). Элиста: Калм. кн. изд-во, 2001. 493 с.

Sobisch, Hyveled 2019 - Sobisch J.-U., Hyveled N. S. Divining with Achi and Tara: comparative remarks on Tibetan dice and mala divination: tools, poetry, structures, and ritual dimensions. Vol. 1. Leiden; Boston: Brill, 2019. $280 \mathrm{p}$

Tshe ring dang 'brug rgyal mkhar 1997 - tshe ring dang 'brug rgyal mkhar. mo dpe sa dpyad rmi lam brtag thabs. lan gru'u: kan su'u mi rigs dpe skrun khang, 1997. 219 р. (= Церинг, Другьял Кар. Тексты гаданий, геомансии и методов исследования снов. Ланджоу: Ганьсуское народ. изд-во, 1997. 219 р.).

existence among the Kalmyks (a case study of E. B. Ubushiev's collection from the Archive of the Kalmyk Scientific Center of the RAS). Oriental Studies. 2018. Vol. 11. No. 3. Pp. 6894. (In Russ.)

Oprya V. Divination Systems of the World. Moscow: Planeta, 1990. 350 p. (In Russ.)

Sükhbat Sh. Traditional Mongolian Divination Systems: Research Methods. Ulaanbaatar, 2002. 93 p. (In Mong.)

Sobisch J.-U., Hyveled N. S. Divining with Achi and Tara: comparative remarks on Tibetan dice and mala divination: tools, poetry, structures, and ritual dimensions. Vol. 1. Leiden; Boston: Brill, 2019. 280 p. (In Eng.)

Todaeva B. Kh. Dictionary of Xinjiang Oirat: Compiled Jangar Epic Narratives and Author's Field Notes. Kalmyk Humanities Research Institute (RAS). Elista: Kalmyk Book Publ., 2001. 493 p. (In Oir. and Russ.)

Tsering D. K. Divination, Geomancy, and Night Dream Interpretation: Texts. Lanzhou: Gansu People's Publ., 1997. 219 p. (In Tib.) 


\section{Факсимиле}

\section{Ойратский текст}

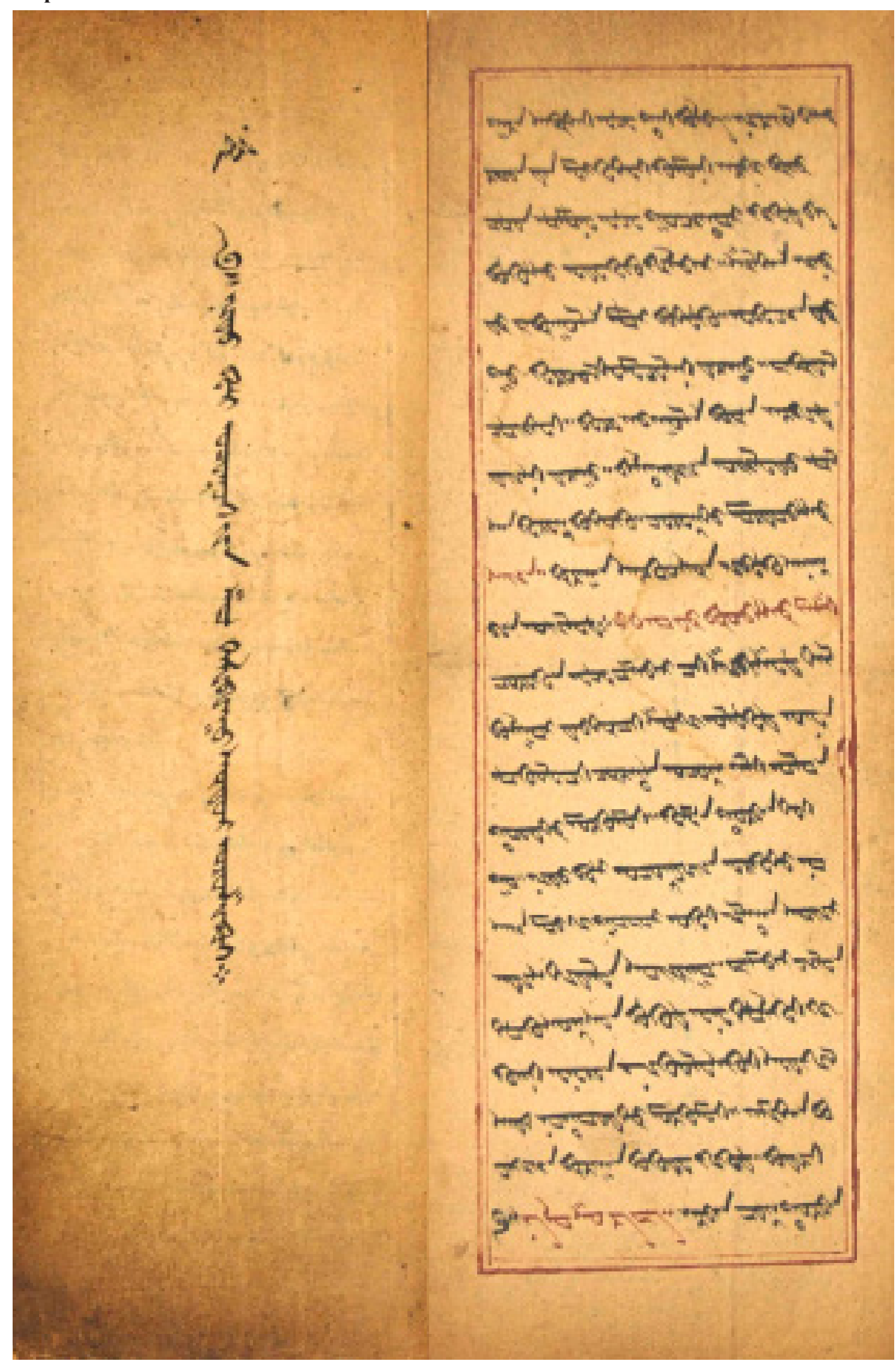


ИСТОЧНИКОВЕДЕНИЕ

SOURCES STUDIES

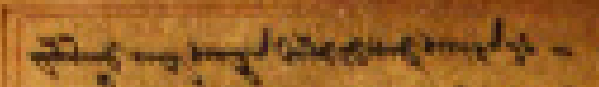
की

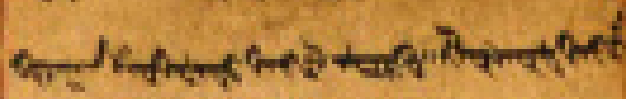
$6+4$ hish

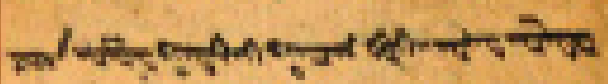

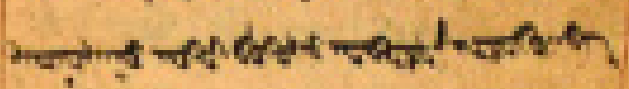

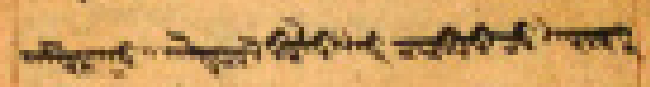

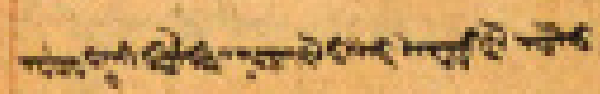

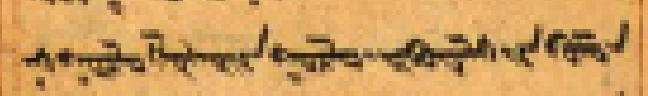

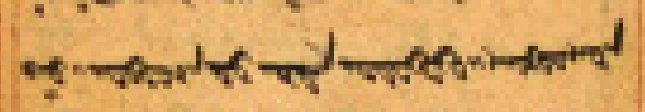

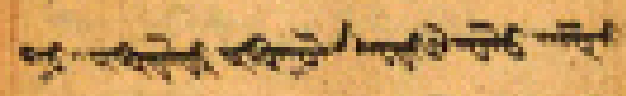

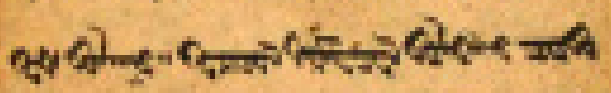

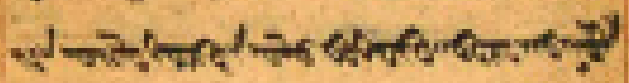

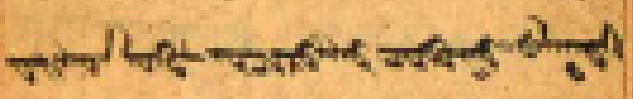

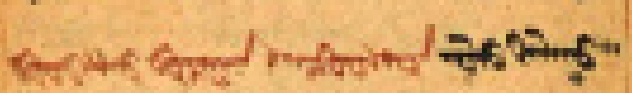

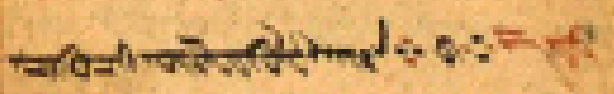

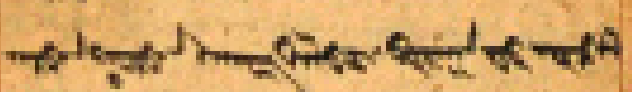

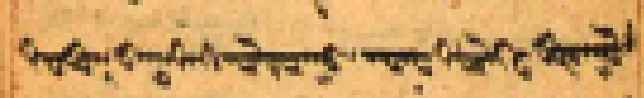

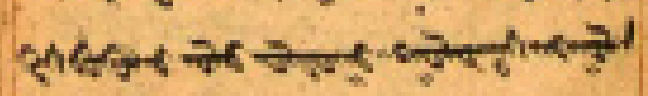

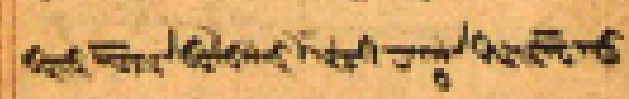

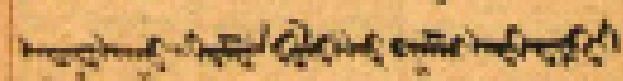

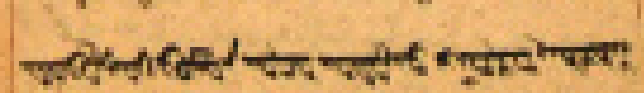

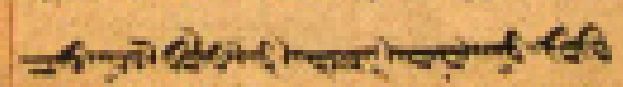

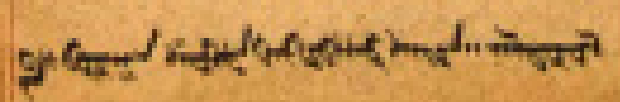

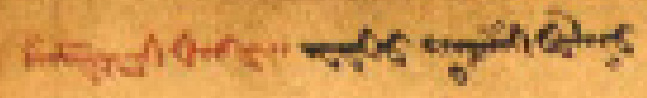

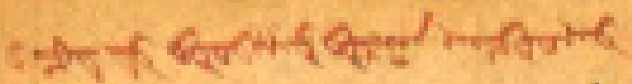

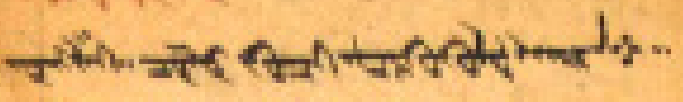

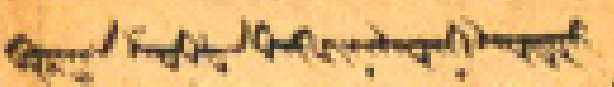

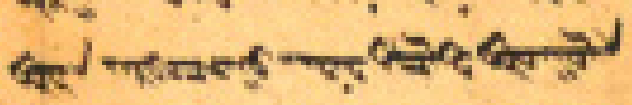

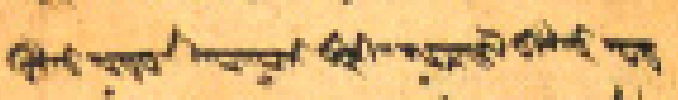

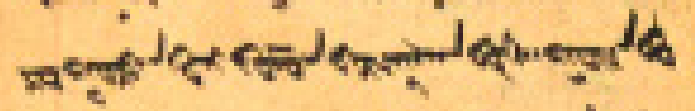

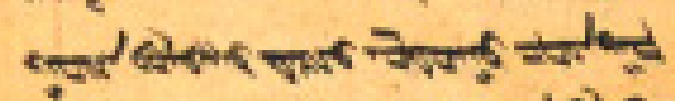

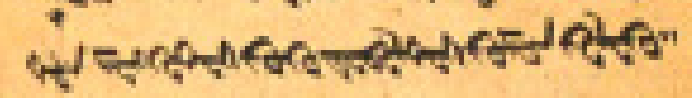

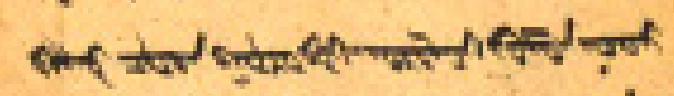

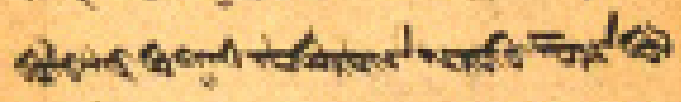

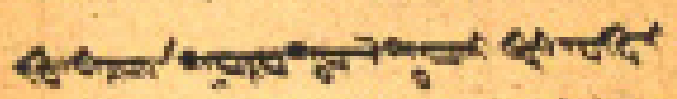

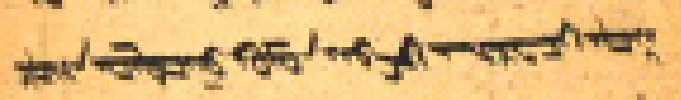

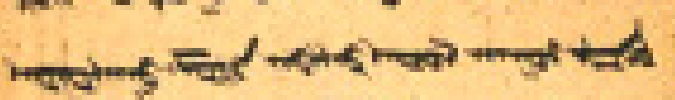
\&

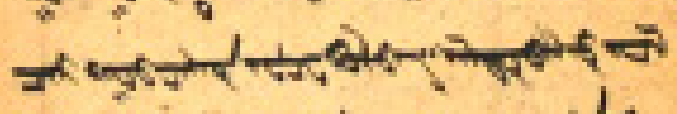

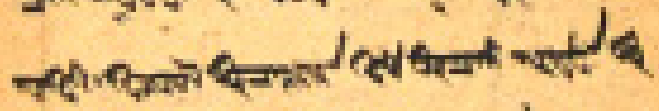

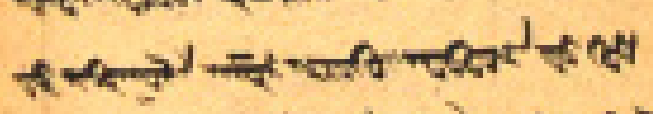

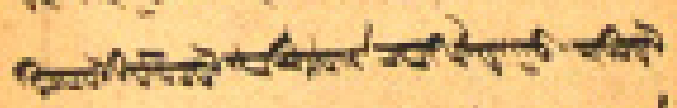

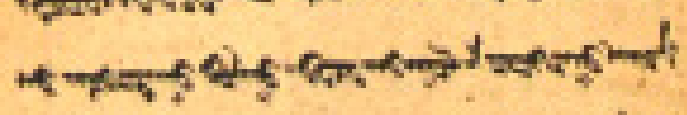

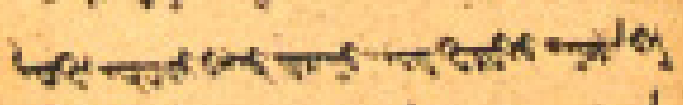

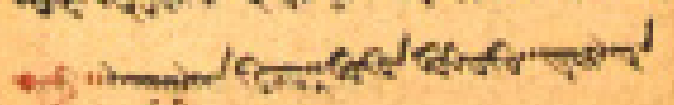

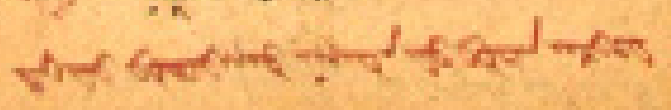

1035 


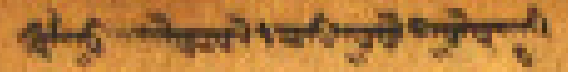
7.

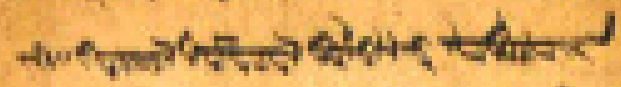

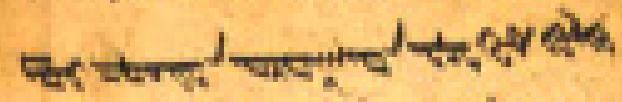

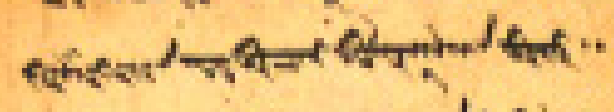

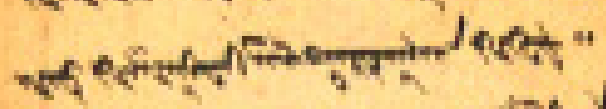

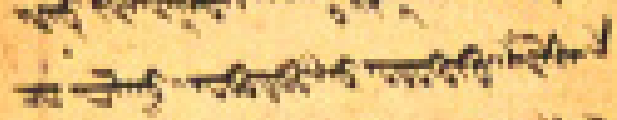

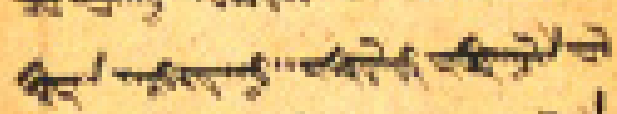

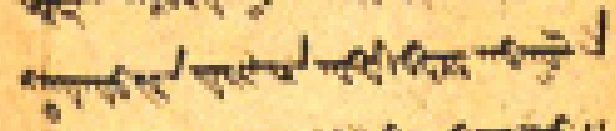

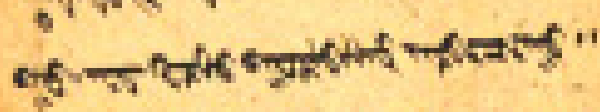

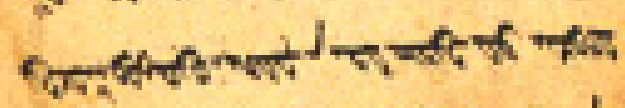

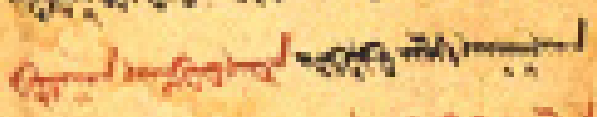

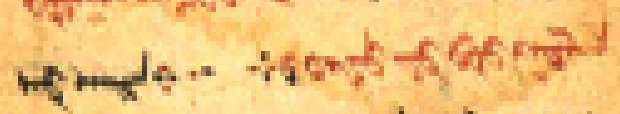

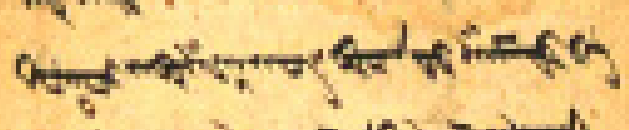

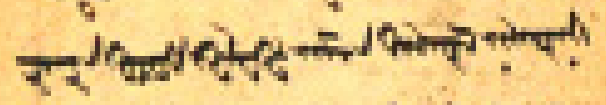

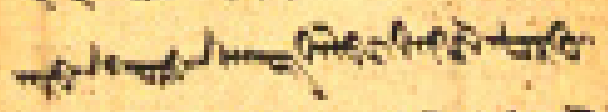

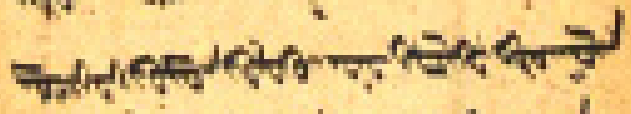
foc 44040 की tum 4 en का Ptwo क/ 4 चे

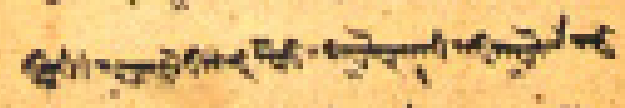

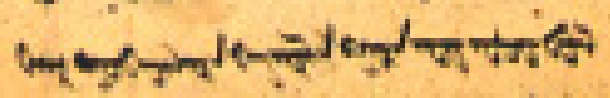

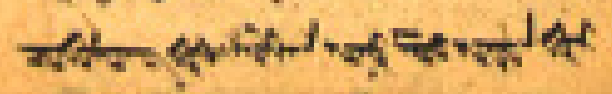

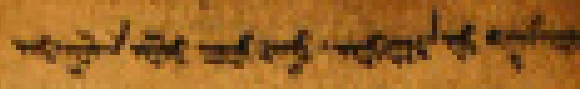

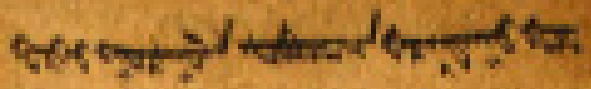

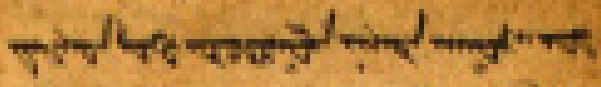

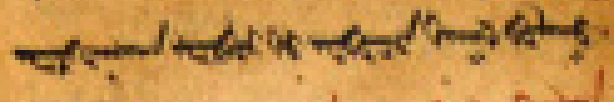

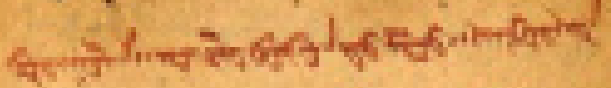

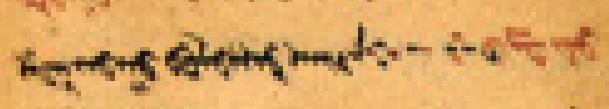

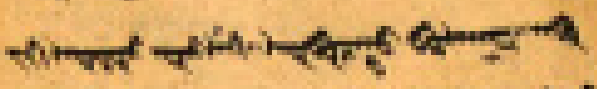

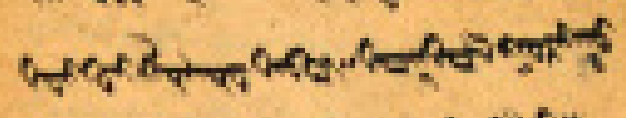

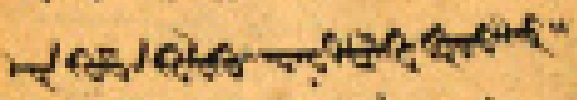

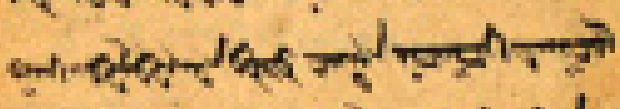
trymentent

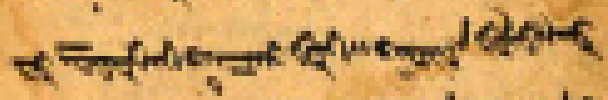

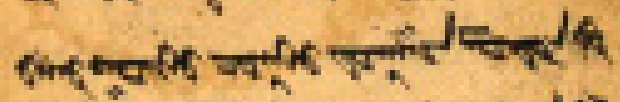

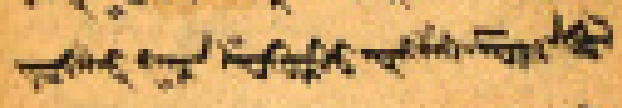

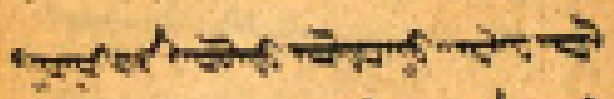

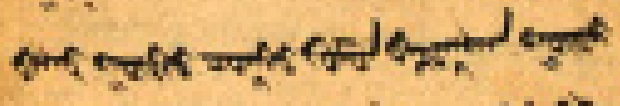

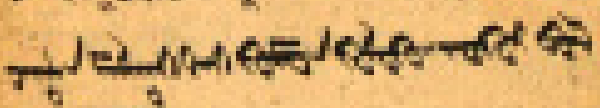

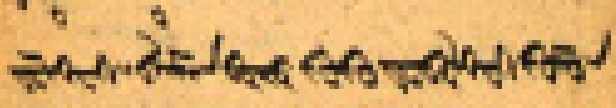

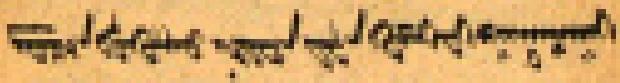

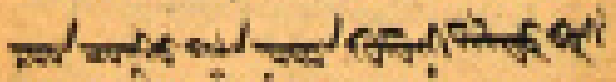

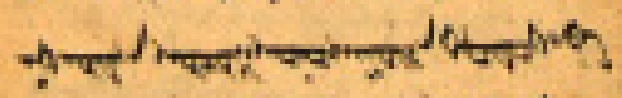

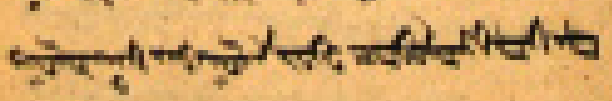

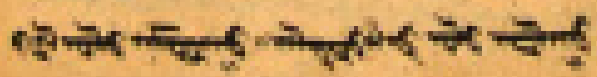

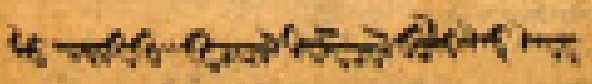

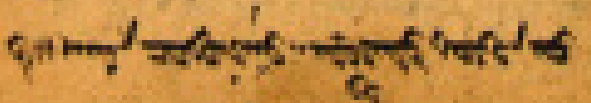




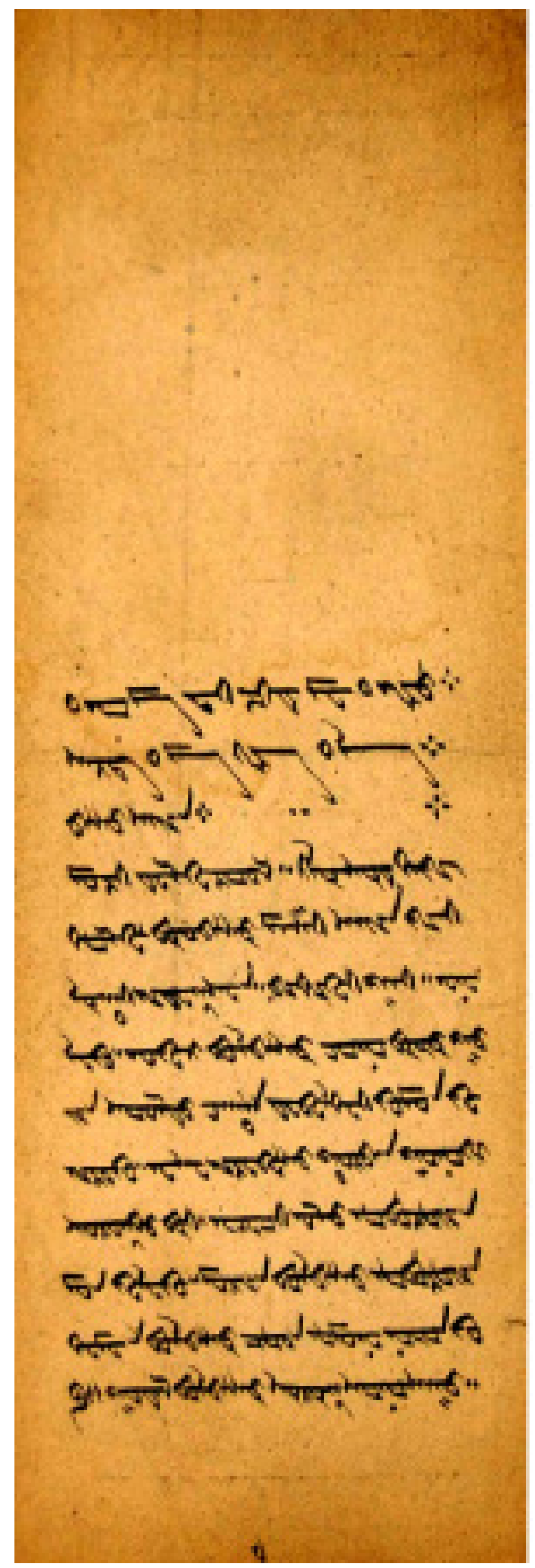




\section{Тибетский текст}

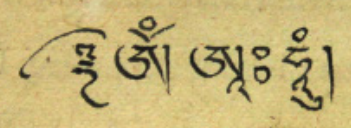

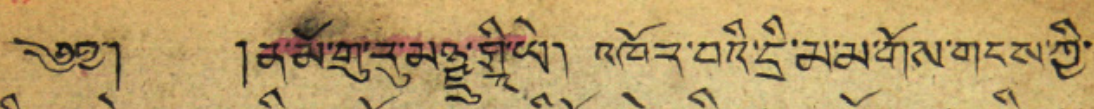

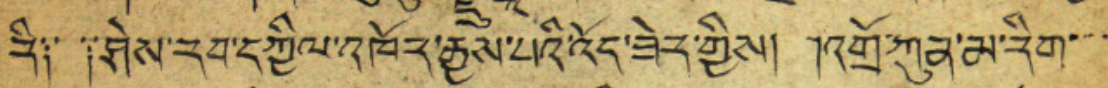

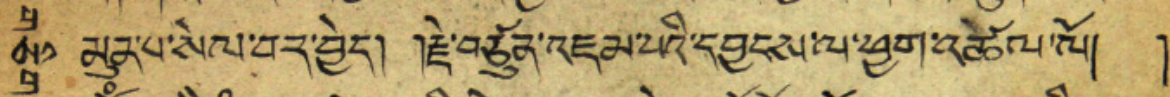

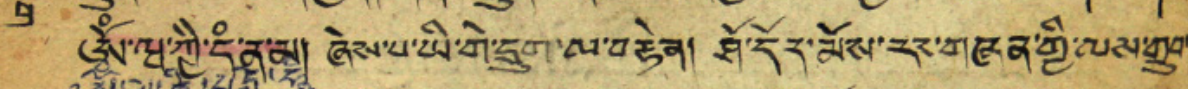

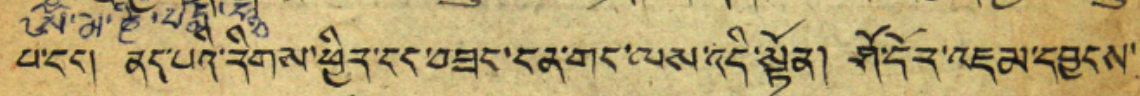

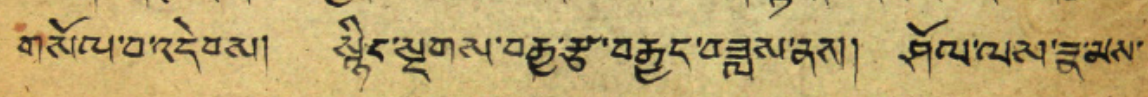

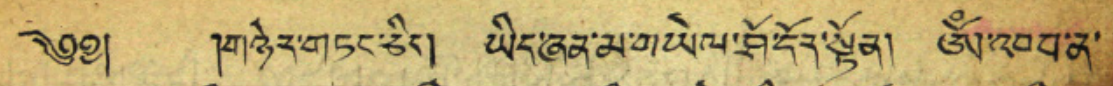

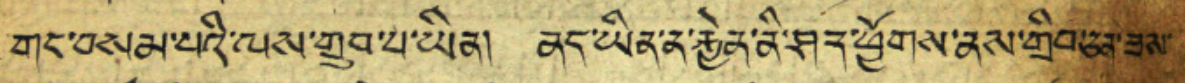

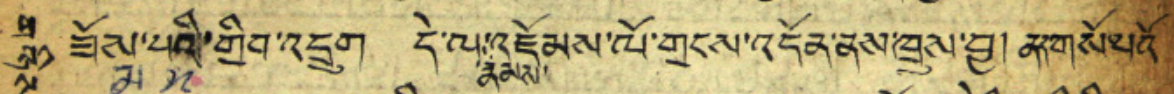

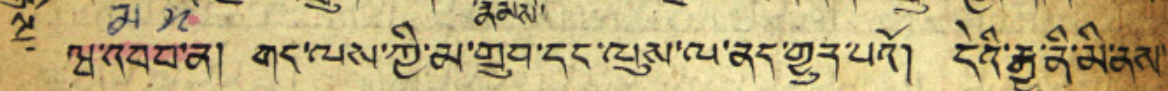

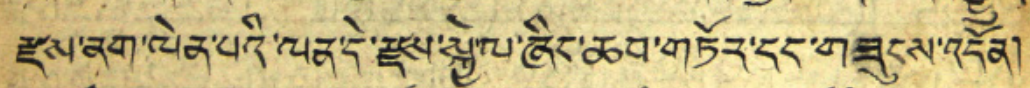

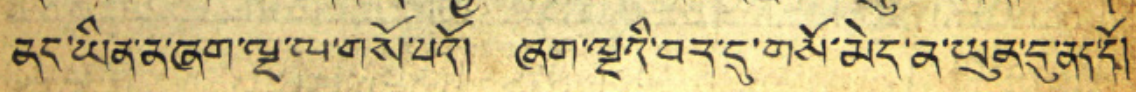




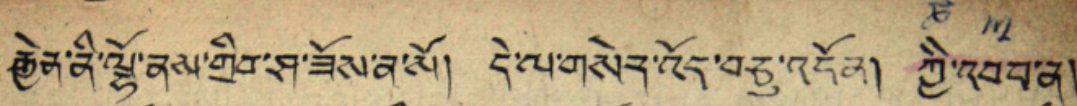

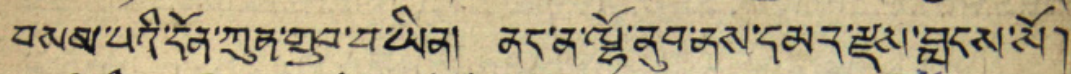

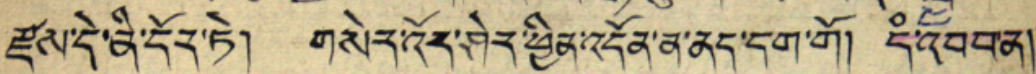

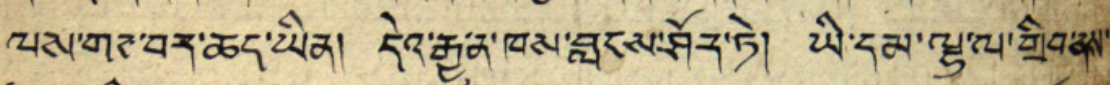

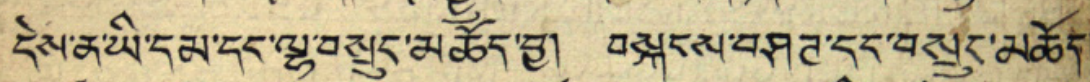

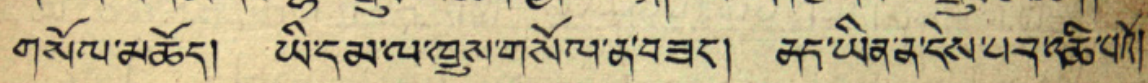

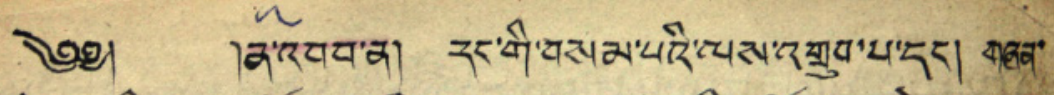

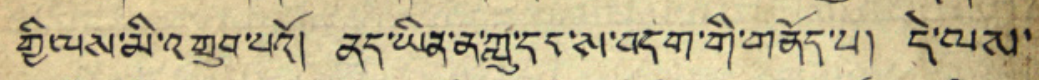

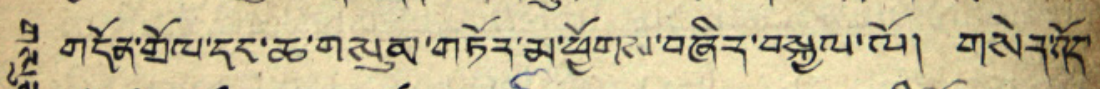

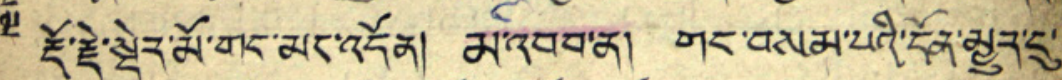

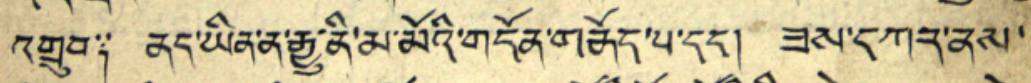

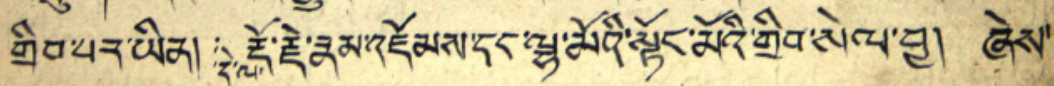

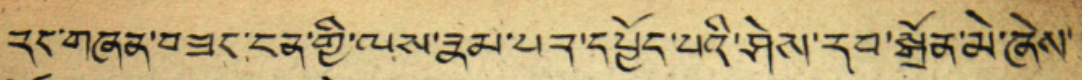

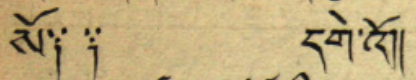

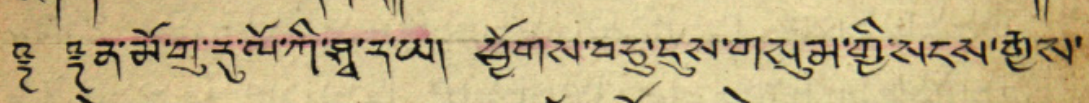

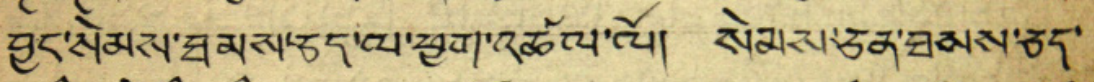

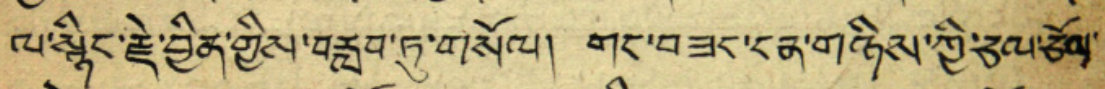

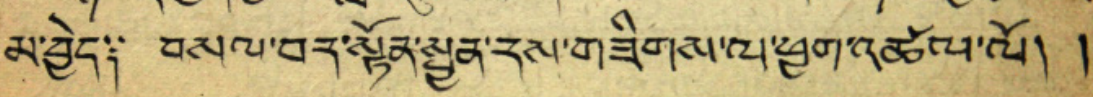

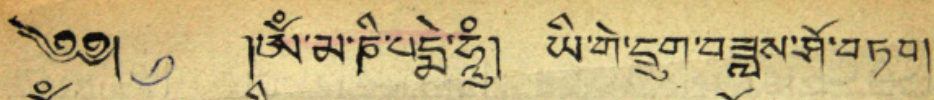

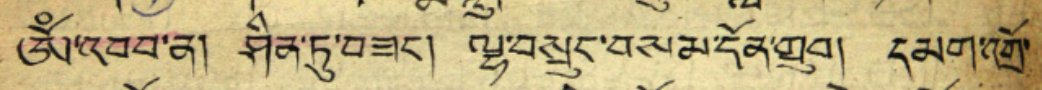

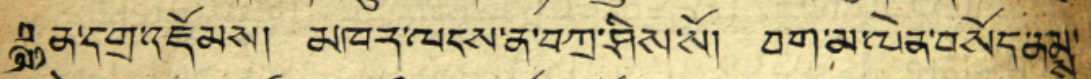

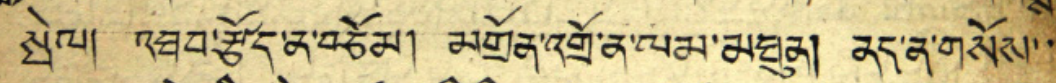

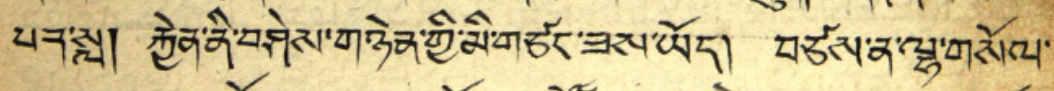

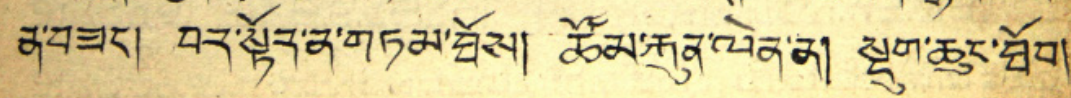




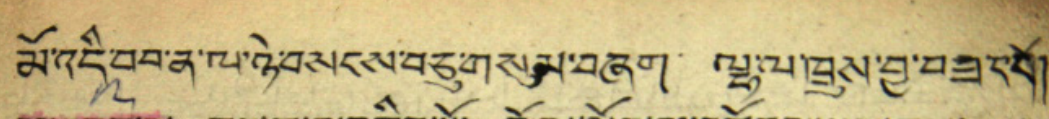

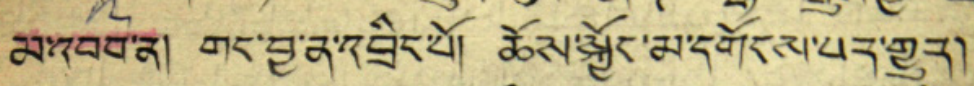

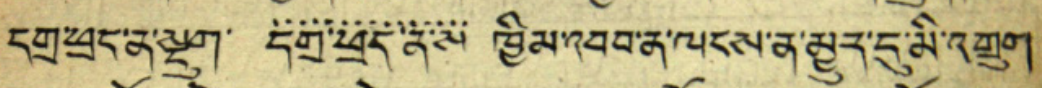

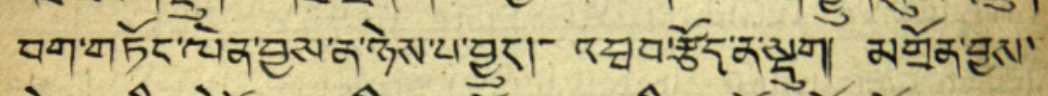

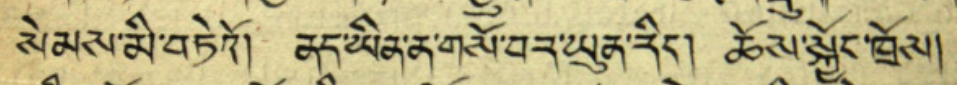

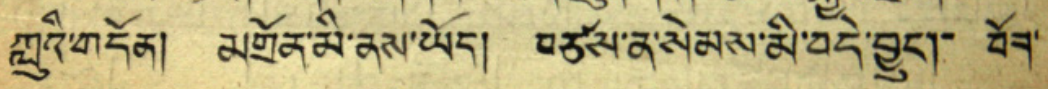

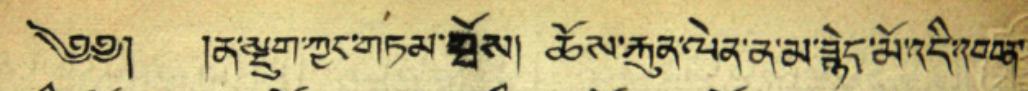

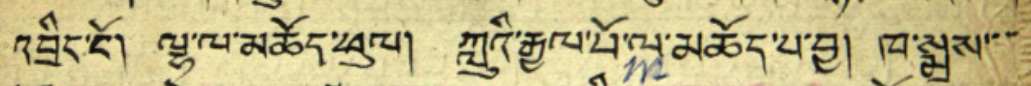

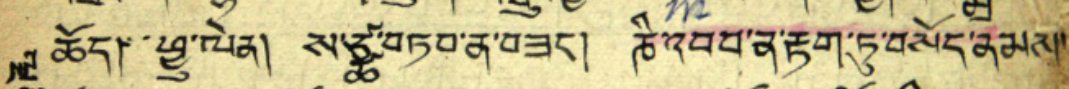

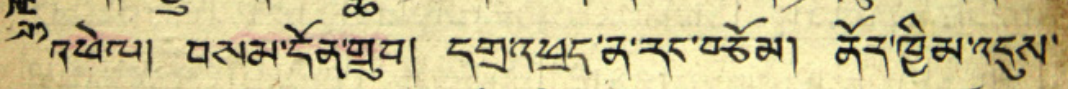

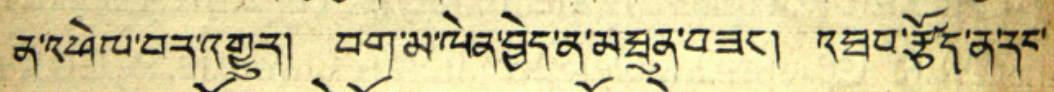

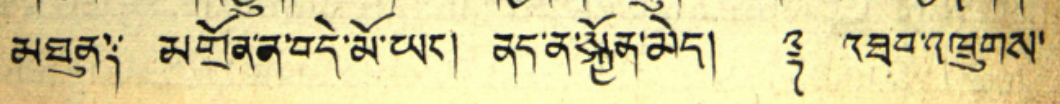

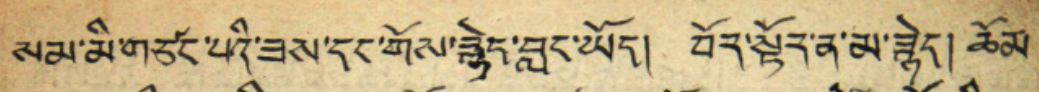

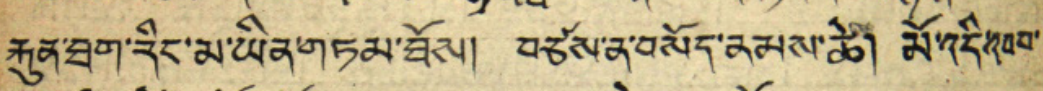

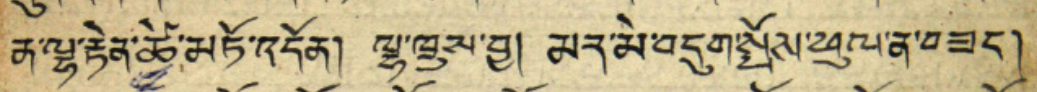

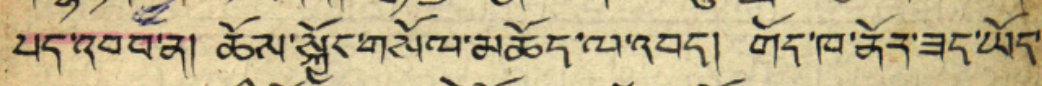

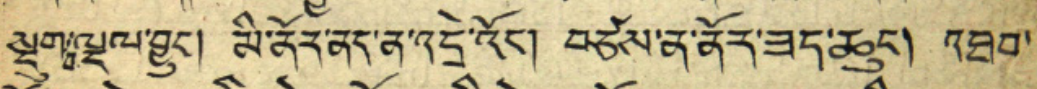

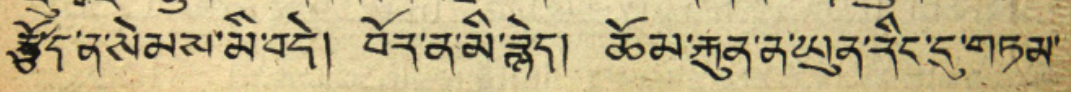

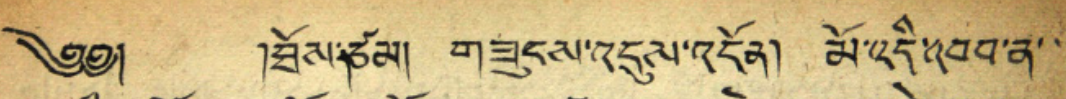

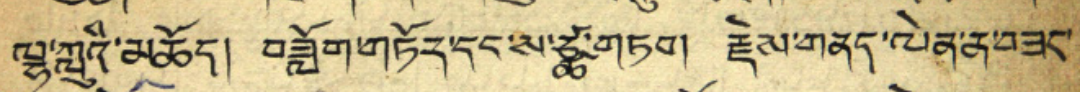

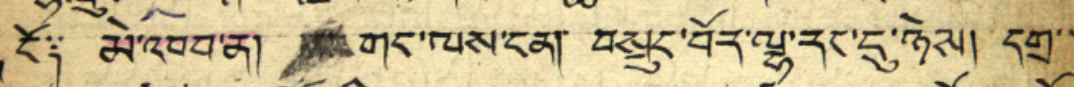

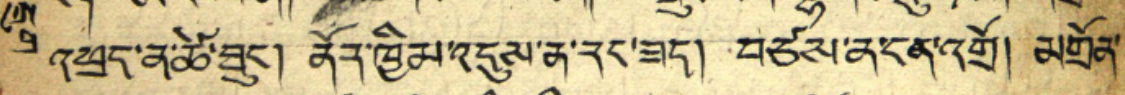

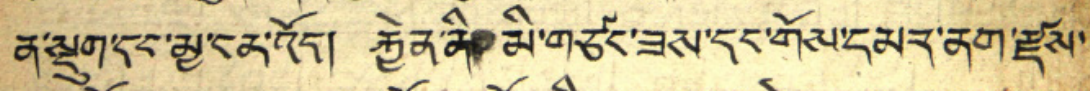

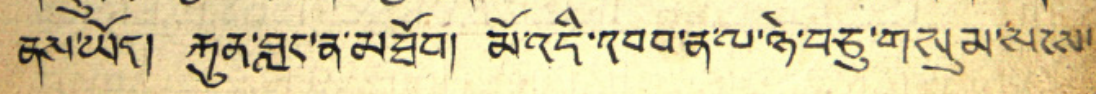




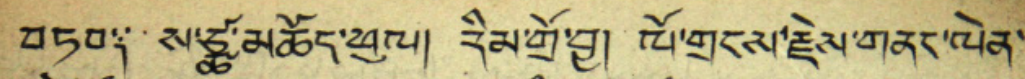

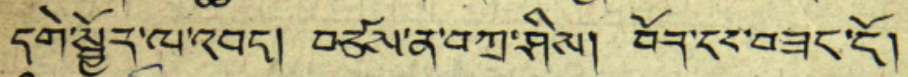

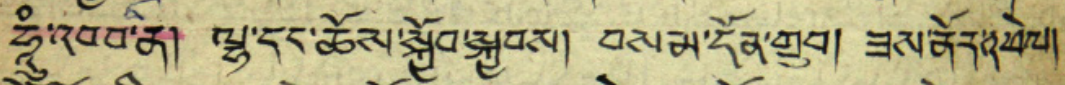

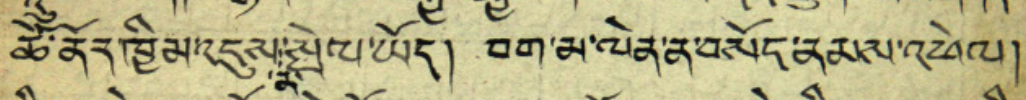

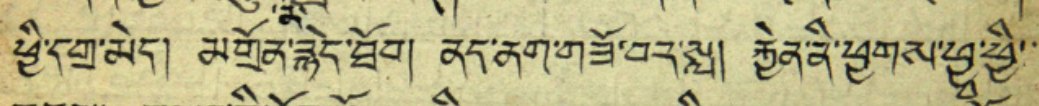

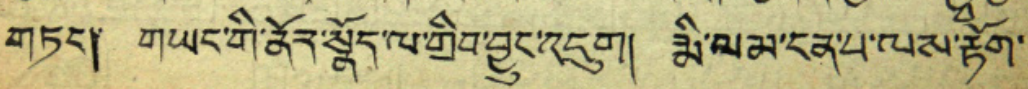

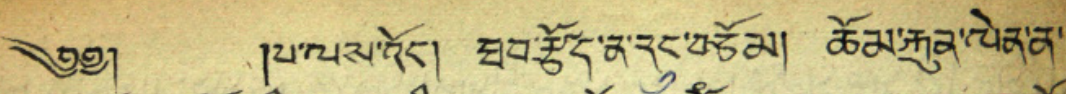

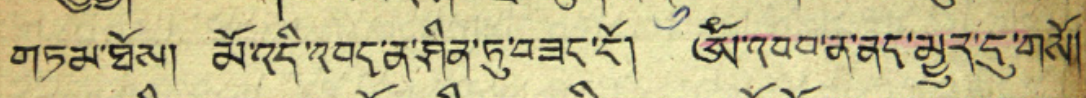

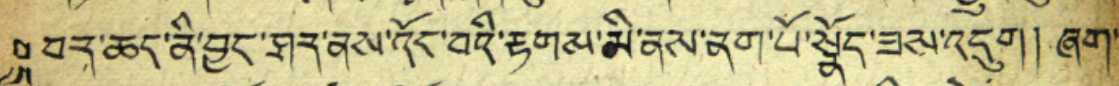

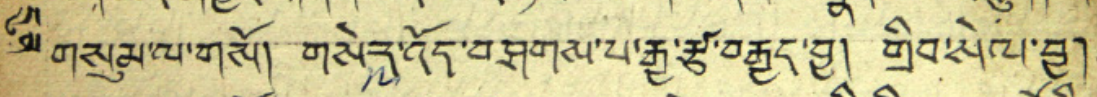

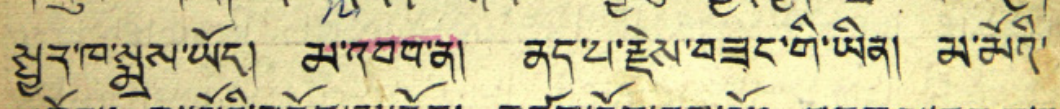

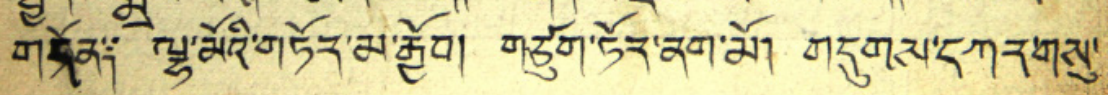

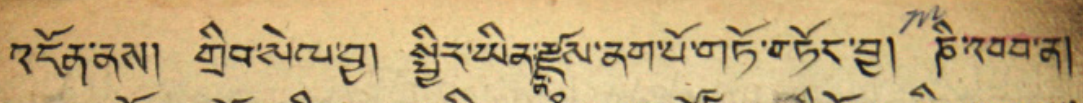

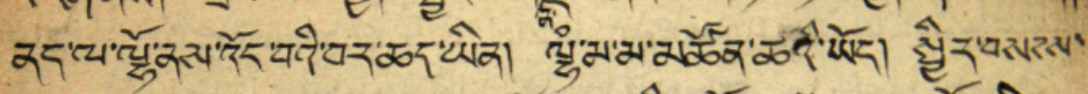

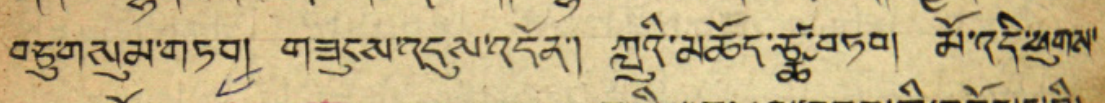

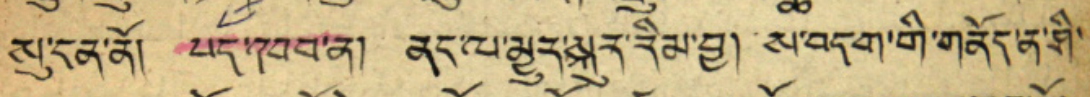

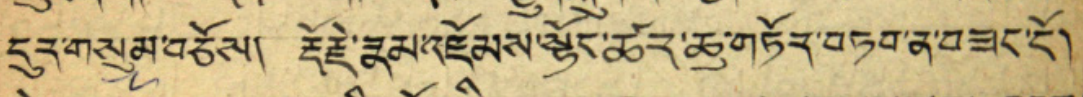

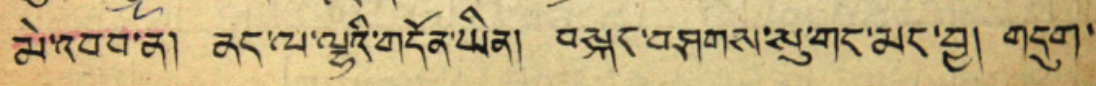

श्ञा

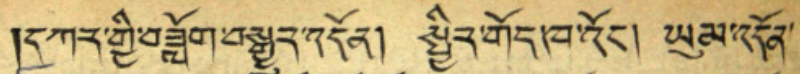

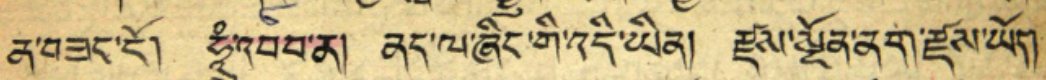

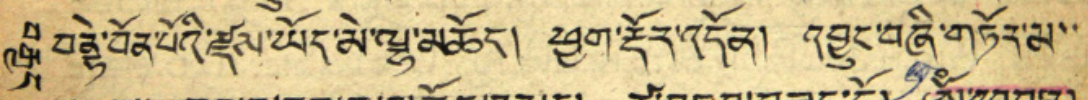

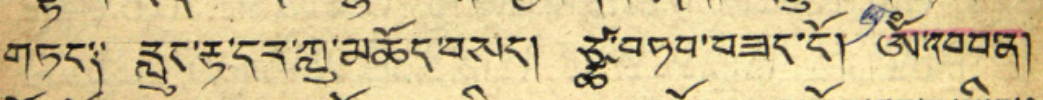

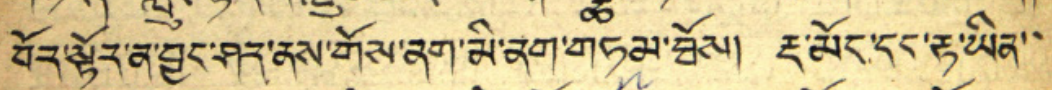

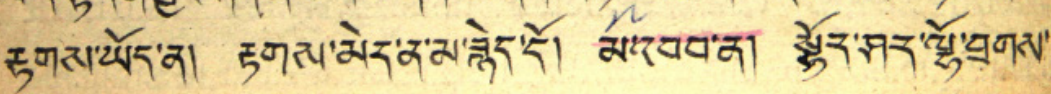




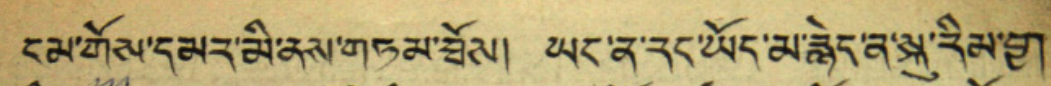

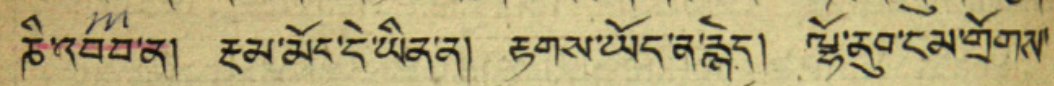

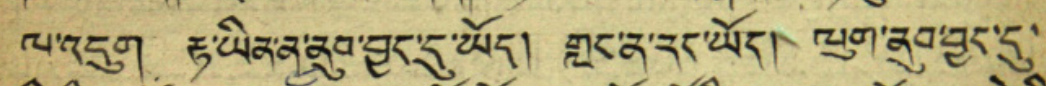

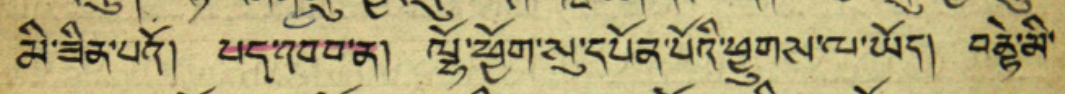

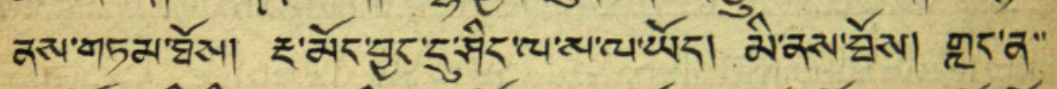

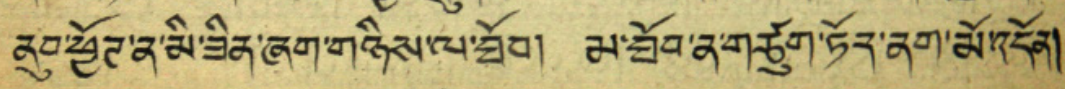

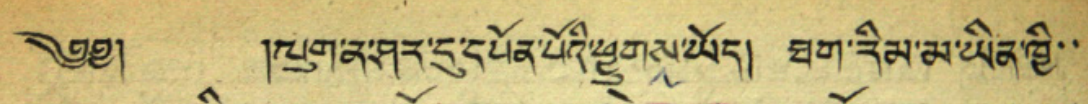

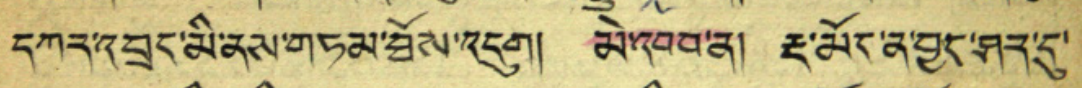

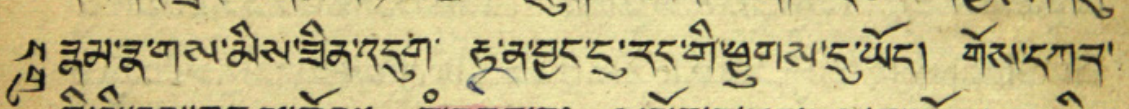

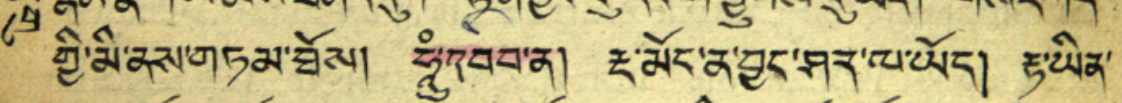

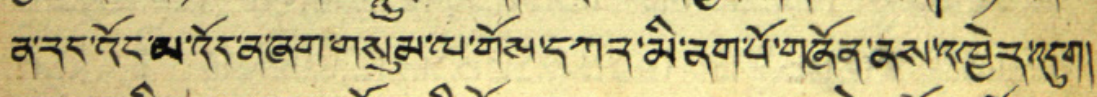

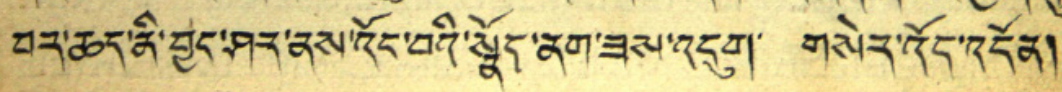

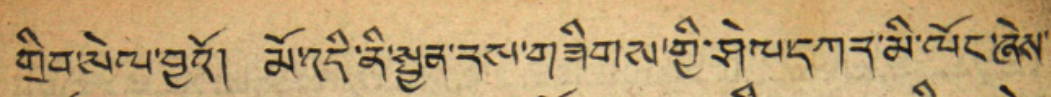

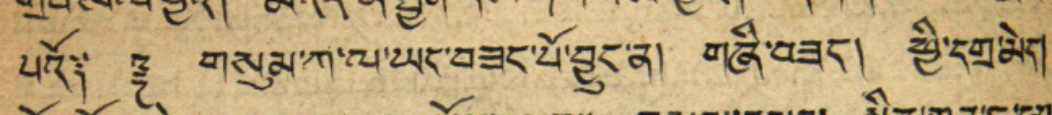

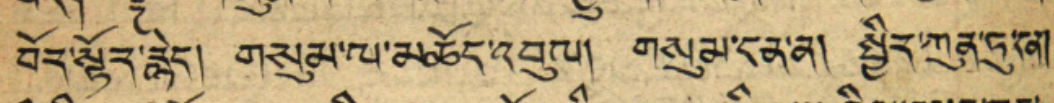

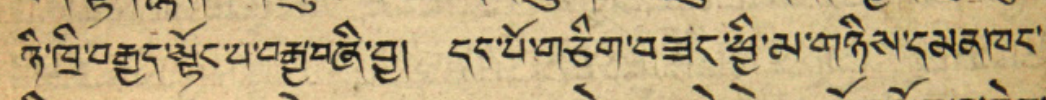

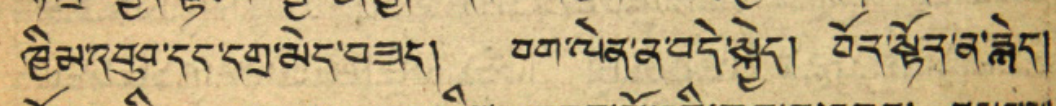

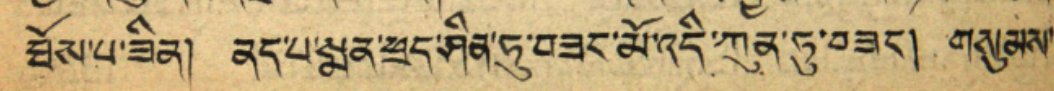

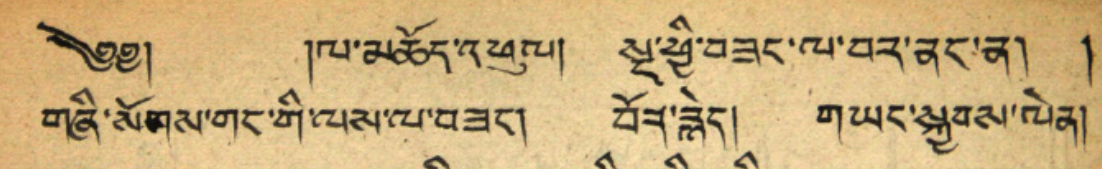

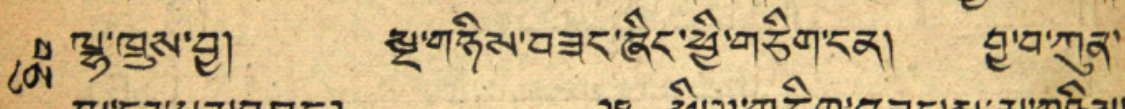

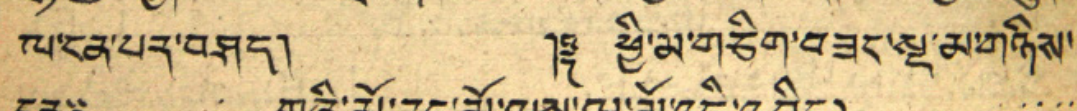

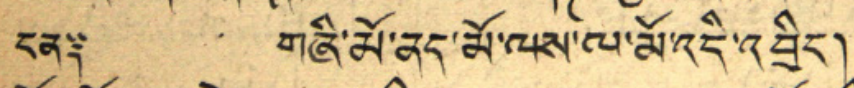

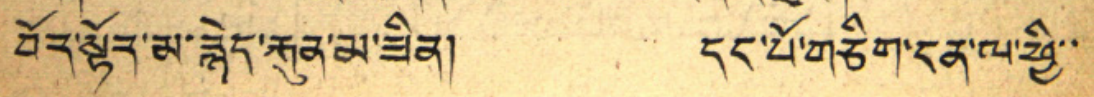



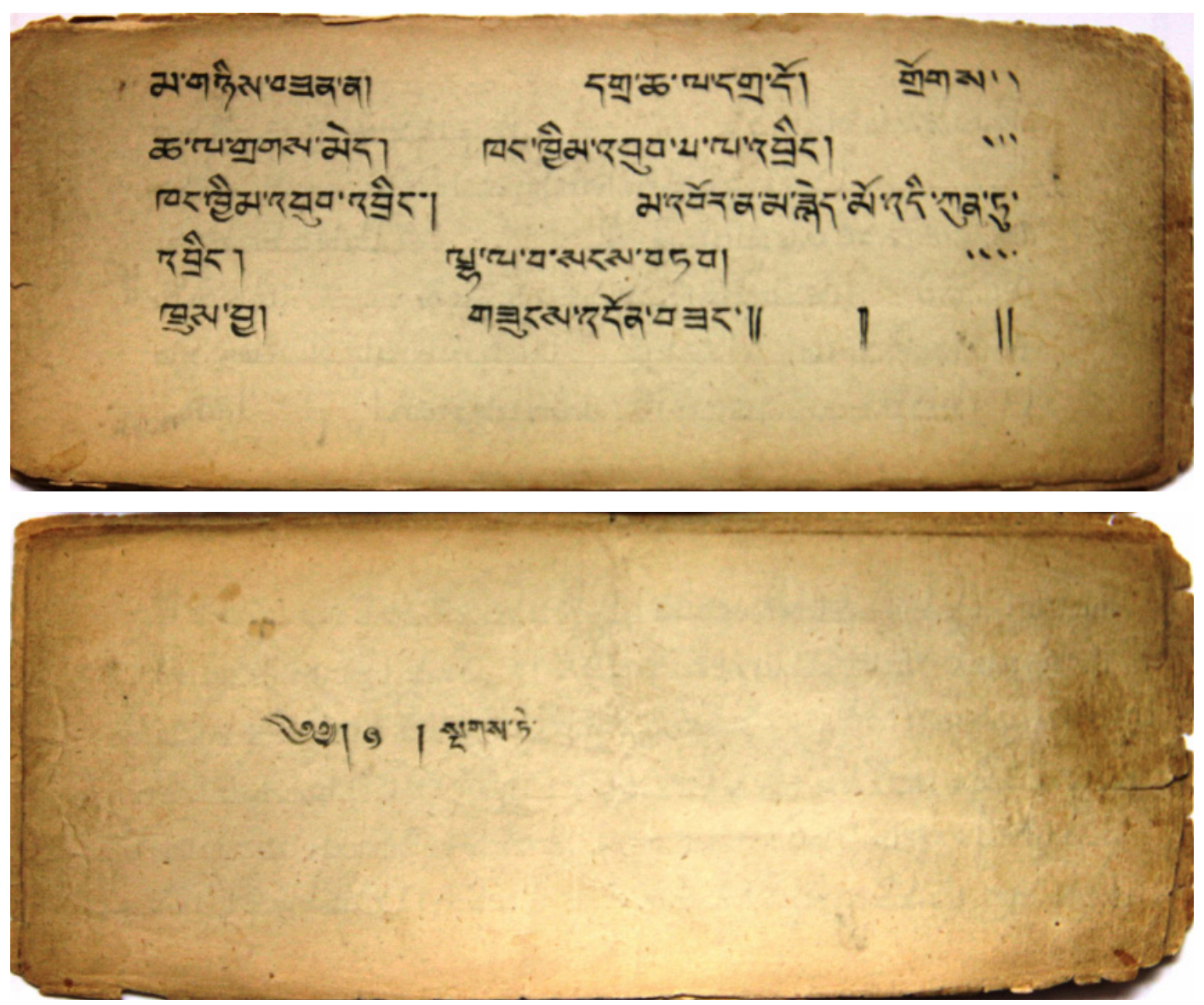

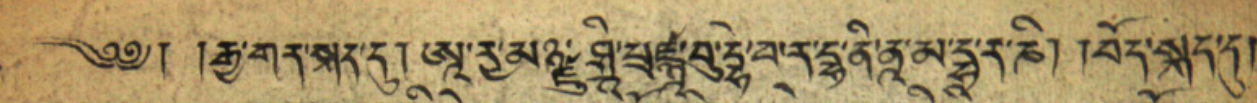

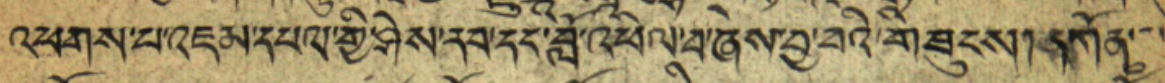

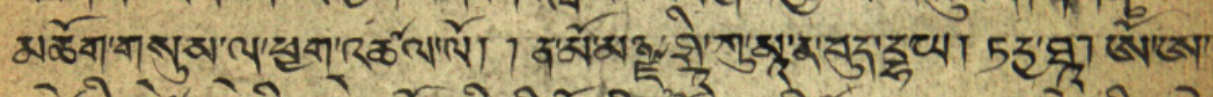

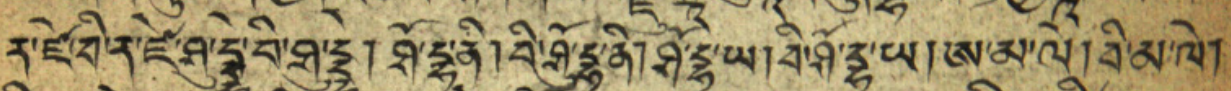

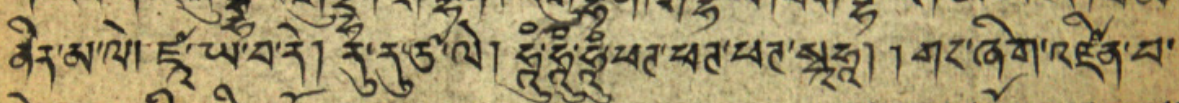

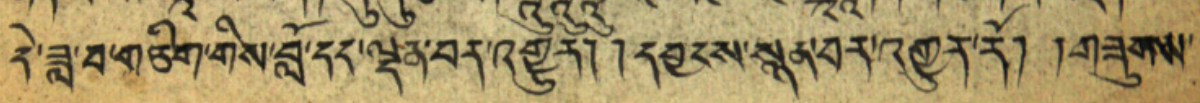

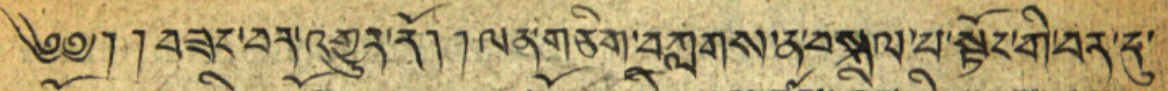

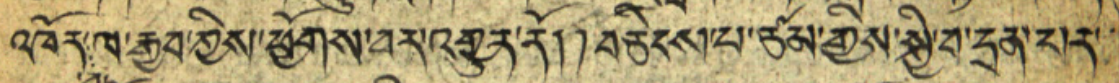

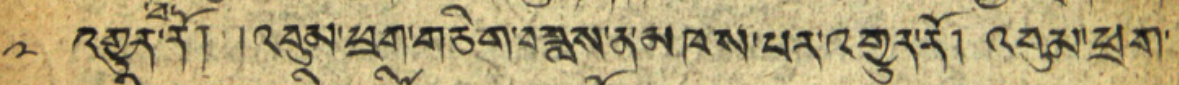

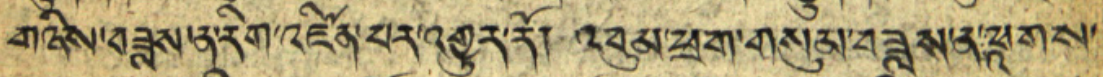

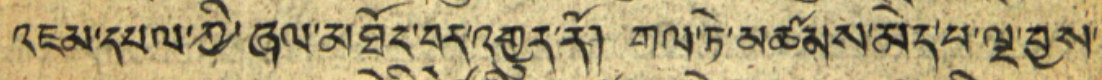

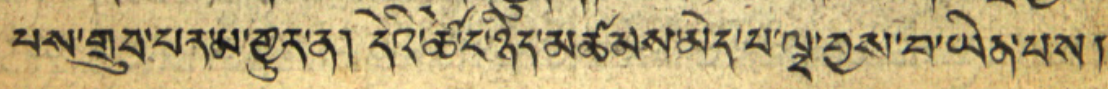




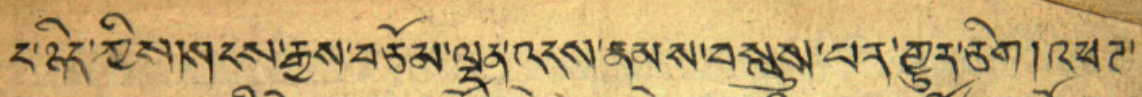

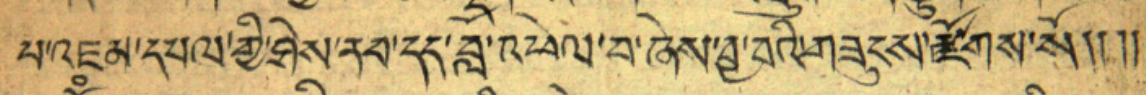

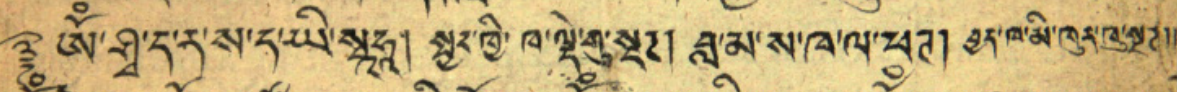

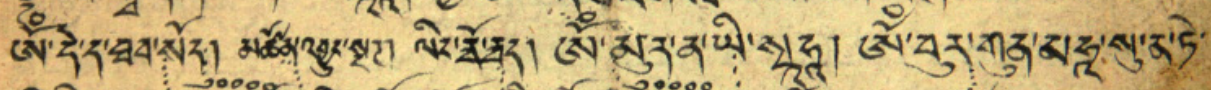

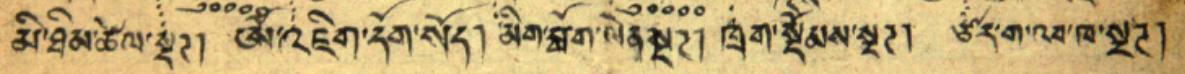

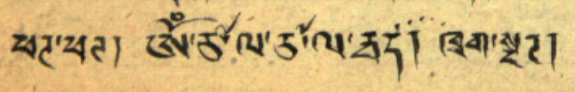

